\title{
Tourmaline studies through time: contributions to scientific advancements
}

\author{
Darrell J. HENRY*, Barbara L. DUTROW \\ Department of Geology \& Geophysics, Louisiana State University, Baton Rouge, LA, 70803, USA; glhenr@lsu.edu \\ * Corresponding author
}

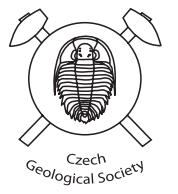

Tourmaline studies have been an integral part of science and scientific exploration for centuries and continue to flourish today. In the $19^{\text {th }}$ century, the curious pyroelectric and piezoelectric properties of this mineral attracted the attention of scientists who considered tourmaline central to a grand unification of the theories of heat, electricity and magnetism. The common occurrence of tourmaline in granites and granitic pegmatites was widely known at that time, but, subsequently, tourmaline was discovered in a great range of igneous, metamorphic and sedimentary rocks and a variety of ore deposits, including hydrothermal systems. The chemical complexity of this mineral became more fully established and "appreciated" by the end of the $19^{\text {th }}$ century.

In the early- and mid- $20^{\text {th }}$ century, tourmaline studies greatly expanded as a consequence of the (1) exploration of wider ranges of geological settings, (2) development of instrumentation to characterize the chemical and physical properties of minerals and (3) the applications that derived from these studies. In clastic sedimentary rocks, tourmaline was identified as one of the most important heavy minerals and became a means to estimate maturity of the clastic sediment, to determine provenance and to make stratigraphic correlations. The crystallography of tourmaline was more fully understood and the overall structure and general structural formula was known by the 1960-1970's. Applications of tourmaline relied originally on its piezoelectric properties that became increasingly important during the $20^{\text {th }}$ century. One application, developed after World War I, was the detection and measurement of conventional and atomic explosion pressures based on tourmaline's piezoelectric properties.

Tourmaline studies have expanded in breadth and greatly increased in number since 1977, when micro-analytical and crystallographic/spectroscopic instrumentation became widely available. Petrologically, tourmaline has become a valuable petrogenetic indicator mineral in rocks and sediments due to its occurrence in most rock types, its extreme P-T range of stability, from the near surface to the deepest levels of the crust, its capacity to attain a chemical signature during the evolution of the rock in which it is formed, its ability to retain that chemical imprint, and its capability to provide specific information on the time, temperature and fluid history of its host rock. More recent studies have greatly expanded the conceptual framework of its internal structure and have dramatically increased the number of tourmaline species from 4 to 33. The future of tourmaline studies is promising with many new and exciting possibilities that will continue to influence scientific inquiry well into the future.

Keywords: tourmaline, history of science, crystallography, spectroscopy, mineral chemistry, petrology

Received: 17 January, 2018; accepted: 15 May, 2018; handling editor: M. Novák

\section{Introduction}

Tourmaline studies have contributed greatly to the advancement of science since the late $18^{\text {th }}$ century and they continue to impact science today. These studies have become increasingly prominent in the last 40 years, and especially in the last 20 years. A dramatic "punctuated evolution" in tourmaline investigations coincided with the Tourmaline 1997 International Symposium on Tourmaline held in Nové Město na Moravě, Czech Republic. This Symposium brought together 78 active, as well as budding, tourmaline researchers from throughout the world. During the meeting, 50 presentations covered a wide range of topics such as mineralogy, crystallography, petrology, experimental tourmaline synthesis, geochemistry, and economic geology. As a direct result of
Tourmaline 1997, 22 tourmaline papers were published in conference special issues of the European Journal of Mineralogy and the Journal of the Czech Geological Society. To highlight the acceleration of the rate and diversity of tourmaline studies following Tourmaline 1997, an extensive, but not comprehensive, review of the literature shows that from 1707 to 1996 (over 290 years) there were 1215 papers published on tourmaline. In contrast, in 1997-2017 there were 1353 papers published on tourmaline at the time of this writing (Fig. 1).

At the 20-year anniversary of Tourmaline 1997, a follow-up conference, the Tourmaline 2017 International Symposium, was held at the same location in Czech Republic, and served as a venue to reflect on the remarkable progress of tourmaline research since 1997. Additionally, the conference participants anticipated the future 


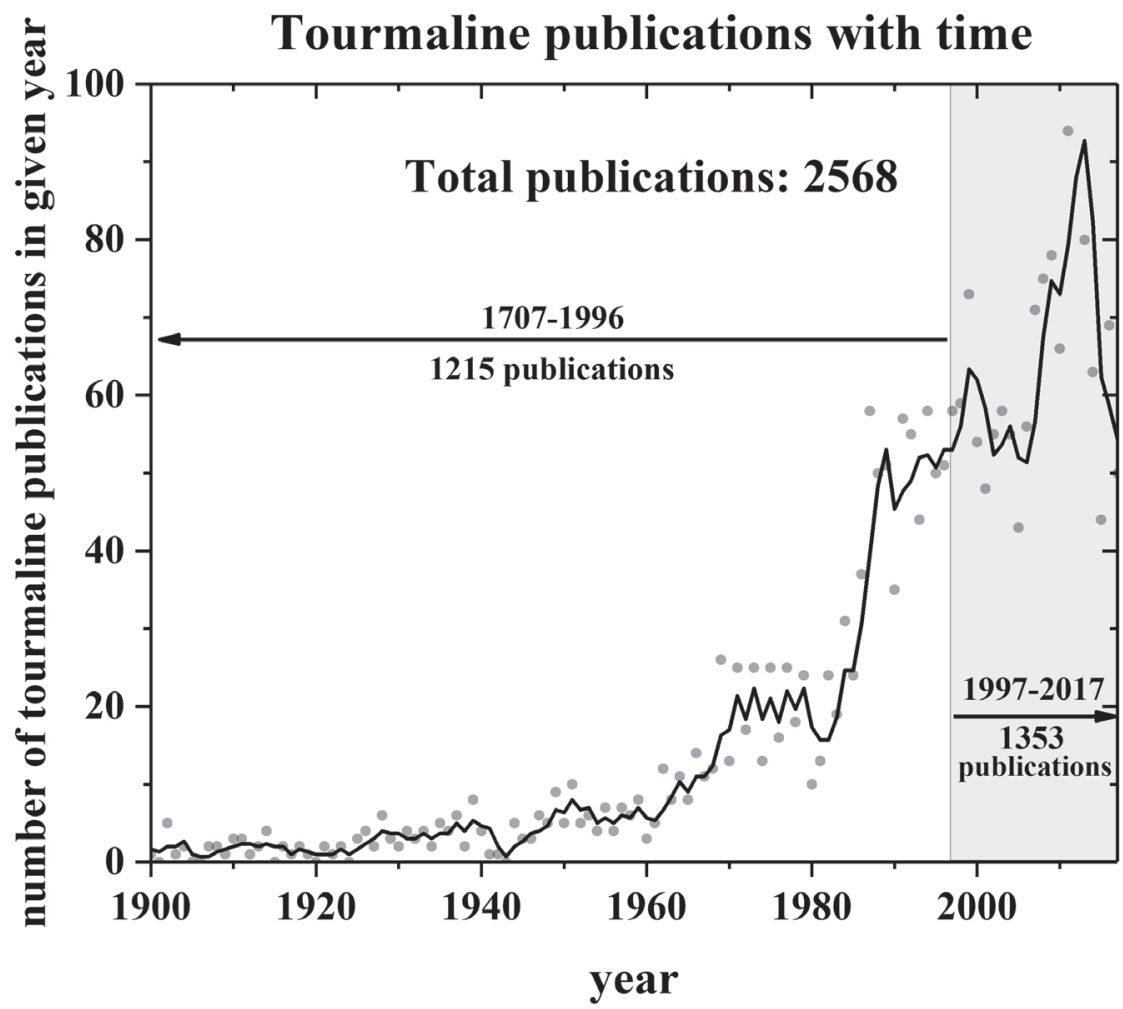

Fig. 1 Numbers of papers published on various aspects of tourmaline from an extensive, but not comprehensive, bibliographic database compiled by the authors. The data are plotted from 1900 to 2017, but publications include those going back to 1707 . The dots are the numbers of papers published in a given year. The solid line represents the yearly number of papers averaged over three consecutive years. The shaded area indicates the last 20 years, showing the dramatic increase in interest, utility and advancements using tourmaline during that time frame. directions of tourmaline studies to be carried out by new generations of tourmaline investigators.

This contribution highlights the history of tourmaline studies with particular attention to the use of this mineral in the evolution of scientific thought, the ever-increasing range of tourmaline research with selected key developments that have advanced the understanding and utility of tourmaline as a scientific tool, and concludes with speculations about possible future directions in tourmaline investigations.

\section{Tourmaline studies from antiquity to 1900}

Tourmaline has been integral to the advancement of science for several hundred years. Much of the early interest in tourmaline was related to its electrical properties - i.e. tourmaline's ability to acquire a differential surface charge on heating/cooling (pyroelectricity) or when pressure is applied along the $c$ axis (piezoelectricity) of the crystal.

In Western literature, the earliest known reference to a material considered to be tourmaline appears in the work of the Greek naturalist Theophrastus (c. 372-287 BC) in De lapidibus ("On Stones"). In this work, he describes a gemstone, lyngurium, that has the color of electrum (yellow) and when heated attracts ash, straw, leaves, and small pieces of copper and iron. Theophrastus compares the properties of lyngurium to amber, but it is most likely that lyngurium is a variety of tourmaline (e.g. Walton 2001). The term tourmaline is considered to be derived from the Sinhalese word turmali, a term used by the gem dealers of Ceylon (currently Sri Lanka) to refer to unclassified mixed-colored stones (Henry and Dutrow 2012b).

Tourmaline has been used as a gemstone since at least the Middle Ages, sometimes inadvertently. For example, the $14^{\text {th }}$ century Czech crown of Saint Wenceslas, made for the Holy Roman Emperor Charles IV, featured a large red "ruby". This stone is now known to be a red tourmaline (Hyršl and Neumanová 1999; Henry and Dutrow 2012b). Tourmaline's use as a gemstone was intermittent until the late $19^{\text {th }}$ century when the Dowager Empress Ts'u Hsi of China popularized pink tourmaline as a gemstone (e.g. Fisher 2008; Pezzotta and Laurs 2011). However, the electrical effects that tourmaline exhibits are what caught the attention of the scientific community.

In early $18^{\text {th }}$-century Europe, as traders returned from Asia, they noted the fascinating electrical properties of tourmaline fragments found among rough precious stones. Dutch traders gave this material the name ashentrekker ("ash puller") because of its ability to attract ashes from pipes when the stone was heated or cooled. In a 1707 account, Johann Georg Schmidt describes tourmaline as having "the property of not only attracting the ashes from the warm or burning coals, as the magnet does iron, but also repelling them again... "(Lang 2004). Carl von Linné (Linnaeus) further enhanced the scientific 
status of tourmaline by giving it the name lapis electricus ("electric stone") in 1747 - a clear reference to the electrical properties of tourmaline (Gautschi 2002). In 1756, systematic scientific investigations by Franz Aepinus established the nature of its electrical properties by showing that heated tourmaline crystals acquire opposite charges at opposite ends (faces) - a property later termed pyroelectricity by David Brewster in 1824 (Home 1976; Lang 2004). Shortly thereafter, in 1766, Johann Wilcke heightened tourmaline's significance by suggesting that tourmaline's properties may lead to a grand unification of the theories of heat, electricity and magnetism (Dietrich 1985). In the late $19^{\text {th }}$ century, tourmaline was found to also exhibit piezoelectric properties, i.e. differential electrical charges developed at opposite poles when the crystal was subjected to stress along the $c$ axis. The brothers Pierre and Jacques Curie first publicized this phenomenon for a small group of materials, including tourmaline, in 1880 (Lang 2004). The electrical properties observed in tourmaline had a major influence on physics in the $19^{\text {th }}$ and early $20^{\text {th }}$ centuries, and would later have significant and interesting societal applications.

The $19^{\text {th }}$ century also brought the beginning of an understanding of the complex chemical composition of tourmaline. Although the first known analysis of a tourmaline species, schorl, was presented in 1785 (Wiegleb 1785), an important constituent of the mineral was missing because it was not until 1808 that the element boron was discovered. Some of the early-defined tourmaline species such as schorl and dravite were chemically characterized with a variety of wet chemical techniques (e.g. Klaproth 1810; Tschermak 1884). As the $19^{\text {th }}$ century progressed, the analytical approaches improved and the wide range of elements that can be incorporated in tourmaline became known. Commensurate with these chemical advancements, crystallographers attempted to develop a general structural formula (e.g. Gruner 1820; Riggs 1888; Scharizer 1889; Penfield and Foote 1899). The full appreciation, and exasperation, of the chemical complexity of tourmaline was ultimately expressed in the statement by John Ruskin (1894) when he described the chemistry of tourmaline as... "on the whole, the chemistry of it is more like a medieval doctor's prescription, than the making of a respectable mineral". He went on to state "but it may, perhaps, be owing to the strange complexity of its make, that it has notable habit which makes it, to me, one of the most interesting minerals".

The other aspect of tourmaline that was considered prior to the $20^{\text {th }}$ century was its lithologic associations. The common association of tourmaline with granites and granitic pegmatites was widely known at that time (e.g. Hamlin 1873; Scharizer 1889). In addition, other associations such as schists and tin ores were documented (e.g. Collins 1883; Patton 1899). Thus, its widespread occurrence in numerous rock types was beginning to be recognized.

\section{Tourmaline studies from 1900 to 1977}

Tourmaline studies greatly expanded in the early-to-mid $20^{\text {th }}$ century. This expansion was primarily in response to the recognition of its occurrence in diverse geological settings and to the development of more accurate instrumentation allowing characterization of the chemical and physical properties of minerals. The ending year of 1977 was chosen as a time marker because it was twenty years prior to the Tourmaline 1997 meeting and it marked a great expansion in the number and variety of tourmaline studies in the modern era (Fig. 1).

\subsection{Electrical properties of tourmaline}

Piezoelectric properties of tourmaline became increasingly important during the $20^{\text {th }}$ century. One application that was developed after World War I was the detection and measurement of explosion pressures (Keys 1921, 1923). This application became increasingly important as World War II arrived and the search for low-Fe tourmalines, used in underwater blast-detection devices, led to significant international intrigue in obtaining quality tourmalines during the war years (e.g. Frondel 1948; Switzer 1974; Dietrich 1985). Subsequent to World War II, tourmaline-based piezoelectric pressure sensors continued to be used and improved with applications related to shock wave, explosion and blast detection (including atomic detonations) in environments up to $700^{\circ} \mathrm{C}$ (e.g. Dietrich 1985; Tressler et al. 1998; Zu et al. 2016).

\subsection{Petrologic associations of tourmaline}

In the early and mid- $20^{\text {th }}$ century, the number of lithologic associations of tourmaline continued to increase as it was found in a wider range of igneous, metamorphic and sedimentary rocks as well as in a variety of ore deposits. In fact, there are many more rock types that do contain tourmaline than those rock types that do not contain tourmaline.

\subsubsection{Igneous and metamorphic rocks}

Tourmaline was largely considered a mineral found in 'hard rocks'. Its existence in an expanding array of igneous and metamorphic rocks was noted in the early- and mid-20 $0^{\text {th }}$ century and includes some associations that might be considered relatively unusual as well as unexpected. Orbicular concentrations of tourmalines were first 
described in leucogranites from several different localities (e.g. Watson 1902; Tilley 1919; Edwards 1936). In addition, tourmalines were identified in increasingly diverse lithologic settings that included: tourmaline-corundum rocks (Scrivener 1910), serpentinites (Duparc and Siggs 1914; LaCroix 1914), marbles or contact-metamorphic calc-silicate rocks (Bruce 1917; Tilley 1951), iron formations (Slawson 1936), shear zones (Kramer and Allen 1954), stylolites in sandstones (Heald 1955), blueschists (Branche and Ropert 1956), eclogites (Smith 1971), and granulites (Schreyer et al. 1975). In addition, tourmalinization of country rocks proximal to boron-rich lithologies, such as tin deposits or fractionating granitic pegmatites, was more frequently described (e.g. Irving 1937; Slivko 1955; Hutchison and Leow 1963; Hall 1971).

\subsubsection{Sedimentary rocks and diagenesis}

With the development of the petrographic microscope, small detrital tourmaline was discovered in sediments and sedimentary rocks in the $19^{\text {th }}$ century (e.g. Wethered 1888), but important observations were made and their applications established in the $20^{\text {th }}$ century. Tourmaline was identified as one of the most common heavy minerals, together with zircon and rutile. These minerals became significant because of their mechanical and chemical stability in clastic sedimentary environments (e.g. Brown 1929). Furthermore, determination of the relative ratios of zircon : tourmaline : rutile, the ZTR index, became a useful and widespread method to estimate the maturity of a clastic sediment (Hubert 1962).

One of the early provenance studies used the optical properties of detrital tourmaline to source the clastic grains to the Dartmoor granite, United Kingdom (Brammall 1926). This approach became increasingly refined to include information on the grain size, degrees of rounding and types of mineral inclusions. Ultimately, these observations on tourmaline led to an important method to make stratigraphic correlations (Krynine 1946).

Authigenic tourmaline nucleating on detrital tourmaline grains was described in weakly metamorphosed Bolivian shales (Brammall 1921), and was later found with greater frequency as it became recognized (e.g. Spencer 1925; Stow 1932; Alty 1933). Acicular, probably authigenic, tourmaline was further discovered in salt deposits and in the cap-rock of a salt dome from Louisiana (Brown 1931; Popov and Sadykhov 1962).

\subsubsection{Ore deposits}

In the early $20^{\text {th }}$ century, tourmaline had been known to be an important gangue mineral associated with many types of hydrothermal ore deposits. The near-universal association of cassiterite with tourmaline became a given for most tin deposits (e.g. MacAlister 1903; Spencer 1907). Later, the tin-tourmaline associations were further reinforced in the well-known tin deposits of Cornwall and Bolivia (e.g. Gordon 1944; Hall 1971). As more types of ore deposits were identified, more tourmaline associations were found. Gold-bearing tourmaline-quartz veins were discovered cutting medium-grade schists in Ontario, Canada (Means 1914). Copper-bearing tourmaline breccia pipes were characterized in north and central Chile (Sillitoe and Sawkins 1971). Within the cinnabar deposits of Arizona, Lausen (1926) found a close relation between tourmaline and quartz in metamorphic country rocks.

\subsection{Crystal morphology, crystal chemistry, and crystallography}

During this period, the size and morphological variability of tourmaline was found to be striking. Although elongate, prismatic crystals are the most common morphology, equant or tabular crystals are found (e.g. Dietrich 1985). Very large tourmaline crystals of more than a meter had been found in granitic pegmatites (e.g. Termier 1907; Jahns 1953). In contrast, small authigenic tourmaline of a few micrometers was also discovered. Even tourmalines with fibrous morphology, as first noted by Iyengar (1937), added to the morphological variability. Another morphological variation was observed when tourmaline was partially replaced by other minerals, such that alteration is face specific and occurs most dramatically on the antilogous pole of the crystal.

Prior to 1977, most tourmaline analyses for major and minor elements were done using wet-chemical analytical methods (e.g. Peck 1964; Povondra and Čech 1976). The wet-chemical approach has the advantage that it allows direct analysis of light elements in addition to the different oxidation states of transition elements. However, this "bulk" sample technique has the disadvantages that it is slow, requires exacting analytical skills, has an averaging effect that will mask chemical zoning, and may introduce compositional errors if the tourmaline contains significant amounts of mineral/fluid inclusions. Spectrographic analytical approaches, while valuable, were used to a lesser extent (e.g. Jedwab 1962; Power 1968). Electronmicroprobe analysis of tourmaline became more common in the 1970s, but there were relatively few studies using this approach (e.g. Donnay 1969; Jan et al. 1972).

The crystallography of tourmaline was the focus of many studies throughout the early- and mid- $20^{\text {th }}$ century. The space group and unit cell, initially investigated by Kulaszewski (1921), were based on a hexagonal lattice, but Buerger and Parrish (1937) established that the unit cell for tourmaline is better related to a rhombohedral symmetry with a space group of $R 3 \mathrm{~m}$. The structural formula was disputed for much of earlier part of the century, 
Fig. 2 Number of tourmaline species from 1958 through 2017. Four tourmaline species were "grandfathered" prior to 1958. After IMA was founded, commissions established procedures to name and classify tourmaline species. Two key concepts altered how the tourmaline structural formula was expressed and species defined: (1) F was found to be restricted to the $O(1)$ anion site and the $O(1)$ and $O(3)$ anion sites are considered crystallographically distinct, and (2) some cations exhibit order-disorder in the $Y$ and $Z$ sites (Hawthorne et al.1993). The original general structural formula was modified to include distinct anion groups, $\mathrm{V}[\equiv \mathrm{O}(3)]$ and $\mathrm{W}[\equiv \mathrm{O}(1)]$ (Hawthorne and Henry 1999; Henry et al. 2011). The order-disorder influence on nomenclature is illustrated with the redefinition of ferridravite as povondraite as a consequence of the ordering of $\mathrm{Mg}$ on the $Z$ site (Walenta and Dunn 1979; Grice et al. 1993). The dashed lines represent significant events: the definition of the new general formula for tourmaline (Hawthorne and Henry 1999) and the publication of the first comprehensive tourmaline nomenclature accepted by IMA-CNMNC (Henry et al. 2011). The latter report redefined multiple earlier tourmaline species for nomenclature consistency. The shaded area represents the time after the Tourmaline 1997 International Symposium.

but the overall structure of tourmaline was reasonably well known by the 1960s and 1970s (e.g. Hamburger and Buerger 1948; Belov and Belova 1949; Donnay and Buerger 1950; Donnay and Barton 1972; Buerger et al. 1962).

Based on these crystallographic studies, an early general formula for tourmaline-group minerals was considered to be: $\mathrm{Na}(\mathrm{Mg}, \mathrm{Fe}, \mathrm{Mn}, \mathrm{Li}, \mathrm{Al})_{3} \mathrm{Al}_{6} \mathrm{Si}_{6} \mathrm{O}_{18}\left(\mathrm{BO}_{3}\right)_{3}$ $(\mathrm{OH}, \mathrm{F})_{4}$. By the $1960 \mathrm{~s}$, schorl, dravite and elbaite were the only tourmaline species (e.g. Deer et al. 1962), although uvite had been described earlier by Kunitz (1929).

In 1958, the International Mineralogical Association (IMA) was founded and soon instituted two Commissions to formalize internationally agreed-upon procedures for naming and classifying minerals. These two Commissions were combined in 2006 as the Commission on New Minerals, Nomenclature and Classification (CMNMC) with the mandate "to ensure that strict procedures are followed before new mineral species can be established and before redefinitions and changes to nomenclature can be applied. The CNMNC also coordinates the procedures for classification of minerals." By the end of 1977, the IMA Commissions had recognized six tourmaline species, i.e. it "grandfathered" names for the tourmaline species schorl, dravite, elbaite and uvite [redefined as fluor-uvite in 2011] and recognized buergerite [redefined as fluor-buergerite in 2011] and liddicoatite [redefined as fluor-liddicoatite in 2011] as tourmaline species (Henry et al. 2011).

During this period, as more tourmalines were analysed, some relatively unexpected elements were discovered as important constituents in tourmaline. Cr-rich tourmalines were found in the Barberton district of South Africa (Hall 1918). Vanadium-bearing dravitic tourmaline was initially reported in black quartz-graphite hornfels from Uzbekistan (Badalov 1951). Elevated Ni contents were found in tourmaline from metamorphosed mantle ultramafic rocks (Jan et al. 1972). Significant amounts of $\mathrm{Zn}$ were found in tourmalines from some Li-rich pegmatites (e.g. Jedwab 1962) and fluorine-rich tourmalines were identified with increasing frequency (e.g. Němec 1969). The number of tourmaline species has greatly expanded since 1977 and by the end of 2017 includes 33 species (Fig. 2).

\subsection{High-resolution microscopy, spectroscopy and thermodynamics}

With the development of a variety of high-resolution microscopic and spectroscopic instrumentation methods in the mid-20 $0^{\text {th }}$ century, many of the structural and bonding characteristics of tourmaline were examined. The first high-resolution microscopic investigations of tourmaline were undertaken on buergerite (Iijima et al. 1973). Mössbauer spectroscopy of tourmaline became a method to evaluate the $\mathrm{Fe}^{3+} / \mathrm{Fe}^{2+}$ ratios without having to rely on wet-chemical analytical techniques (Zheludev and Belov 1967; Marfunin et al. 1970; Hermon et al. 1973). The connections among color, chemistry and crystallography in tourmaline came to be understood (e.g. Carobbi and Pierucchini 1947; El-Hinnawi and Hofmann 1966; Manning 1968). Infrared spectroscopic studies of tourmaline began providing insights into the local bonding characteristics of tourmaline, particularly the O-H bonds (e.g. Plyusnina et al. 1969; Vierne and 
Brunel 1970). An initial nuclear magnetic resonance (NMR) study yielded information on charge distribution, coordination and chemical bonding in tourmaline (Tsang and Ghose 1973). Raman spectroscopy, a powerful tool to investigate structural properties of minerals, was slow to be applied because of the complexity of tourmaline, but a few tourmaline Raman spectroscopic studies were conducted prior to 1977 (e.g. Hibben 1939). However, Griffith (1969) made initial progress by systematizing Raman shifts in tourmalines related to the vibrations modes within the rings of $\mathrm{SiO}_{4}$ tetrahedra.

The only theoretical investigation of the thermodynamics of tourmalines prior to 1977 was by Govorov (1971). This study estimated thermodynamic parameters and found that when they are used in thermodynamic calculations, the resulting theoretical stability fields agree with the synthesis experiments of Frondel and Collette (1957).

\subsection{Fluids associated with tourmaline development}

The compositions of aqueous fluids were first found to be fundamental factors in tourmaline stability. The experiments of Frondel and Collette (1957) showed that schorlitic tourmaline is not formed in aqueous fluids that are strongly alkaline and that its growth is inhibited in aqueous solutions with high contents of $\mathrm{Ca}, \mathrm{Mg}$, and Fe relative to $\mathrm{Al}$ and $\mathrm{Si}$.

Tourmaline also serves as a convenient host for fluid inclusions. Early studies of fluid inclusions in tourmalines elucidated that in the highly fractionated Li-rich pegmatites of the Black Hills, South Dakota, USA, aqueous fluids with varying amounts of dissolved salts were trapped (Weis 1953). Using these inclusions, formation temperatures estimated for the pegmatite were less than $500^{\circ} \mathrm{C}$ (Weis 1953), one of the first suggestions of lowtemperature pegmatite formation.

\subsection{Geochronology using tourmaline}

In the mid- $20^{\text {th }}$ century, geochronologic studies using tourmalines were limited to $\mathrm{K}-\mathrm{Ar}$ and ${ }^{40} \mathrm{Ar}-{ }^{39} \mathrm{Ar}$ investigations. In the initial considerations of the potential for the $\mathrm{K}$-Ar geochronological approach, there was concern as to its feasibility because of the typically low contents of $\mathrm{K}$ at the $X$ site and the suspicion that there was retention of excess Ar in the tourmaline structure. Significant excess Ar would result in anomalously old apparent $\mathrm{K}-\mathrm{Ar}$ ages (Damon and Kulp 1958; Dalrymple and Lanphere 1969). Early application of the ${ }^{40} \mathrm{Ar}-{ }^{39} \mathrm{Ar}$ approach using tourmaline was ostensibly better than predicted and, in some cases, provided geologically meaningful ages (Fitch and Miller 1972).

\subsection{Experimental mineralogy and petrology}

The shortage of tourmaline for use in piezoelectric devices during and immediately after World War II sparked the quest to synthesize tourmaline, and essentially launched tourmaline experimental studies (Frondel et al. 1947). Early investigations strictly emphasized synthesis of high-quality tourmaline crystals and crystals with a specific range of cations (e.g. Frondel and Collette 1957; Taylor and Terell 1967; Tomisaka 1968; Ushio and Sumiyoshi 1971).

Limited experimental investigation of the pressuretemperature $(\mathrm{P}-\mathrm{T})$ stability of tourmalines was pursued at this time also. Robbins and Yoder (1962) were the first to experimentally determine that dravite is stable to $865^{\circ} \mathrm{C}$ at $200 \mathrm{MPa}$ and $925^{\circ} \mathrm{C}$ at $500 \mathrm{MPa}$.

\section{Tourmaline studies from 1977 to 2017}

Tourmaline studies have expanded in breadth and greatly increased in number since 1977 (Fig. 1). This fact is partly a consequence of new and improved instrumentation available for tourmaline interrogation. It is also a consequence of important developments in understanding of the nature of tourmaline and its utility as a petrogenetic indicator mineral.

\subsection{Tourmaline petrologic associations and petrogenetic implications}

By the $21^{\text {st }}$ century, tourmaline occurrences were well established in a wide range of igneous, metamorphic and sedimentary rock types (almost wherever boron was available to combine with its other necessary constituents). However, its geologic utility was only enhanced once its capacity to record significant chemical events associated with the evolution of lithologic environments was recognized (e.g. Henry and Dutrow 1996). Several key features of tourmaline enable it to be a much more valuable petrogenetic indicator in rocks and sediments than had been realized in the early- and mid- $20^{\text {th }}$ century.

\subsubsection{Extensive tourmaline stability range}

Tourmaline has an extreme stability range, one of the largest of crustal minerals (e.g. van Hinsberg et al. 2011a). Tourmaline is found in many low $\mathrm{P}-\mathrm{T}$ environments (i.e. $\sim 1 \mathrm{MPa},<150^{\circ} \mathrm{C}$ ) such as: the calcitic cap rocks associated with active salt domes in the Gulf of Mexico, the Karaha-Telaga Bodas geothermal system of Indonesia $\left(\sim 190^{\circ} \mathrm{C}, \sim 3 \mathrm{MPa}\right)$, and the gas fields in Wyoming where tourmaline is a pore-filling authigenic mineral (Gautier 1979; Henry et al. 1999; Moore et al. 2004; Henry and Dutrow 2012a). At the other extreme, 
tourmaline is found at high-temperature $\left(>850^{\circ} \mathrm{C}\right)$ and at ultrahigh pressure (UHP) conditions (>4 GPa) (e.g. van Hinsberg et al. 2011b). Natural UHP occurrences of tourmaline include: the Dora Maira (Alps), a locality where dravitic tourmaline and coesite are included in pyropic garnet; in Erzgebirge (Czech Republic/ Germany), where oxy-schorlitic tourmaline is found in an eclogitic unit that contains coesite and diamond and the Kokchetav Massif (Kazakhstan), where diamonds are included in an unusual K-dominant magnesian tourmaline, maruyamaite (Ota et al. 2008b; Ertl et al. 2010; Dutrow and Henry 2011; Lussier et al. 2016).

The general stability of tourmaline in various fluid compositions is also wide, but more limited. Tourmaline is stable in acid-to-neutral aqueous solutions, but is unstable in alkaline aqueous solutions or where the activities of the cations (including B) and anions in coexisting solutions are unfavourable (e.g. Henry and Dutrow 1996; Dutrow et al. 1999; Dutrow and Henry 2016). The implication is that tourmaline may be a stable mineral at almost all crustal $\mathrm{P}-\mathrm{T}$ conditions, but destabilization within these conditions is predominantly controlled by the destabilizing compositions of the coexisting fluid phase.

\subsubsection{Tourmaline's capacity to retain a chemical signature}

Undeformed tourmaline appears to have extremely slow volume diffusion such that once formed, tourmaline retains the evolving chemical signatures (e.g., Henry and Dutrow 1996; von Goerne et al. 1999; van Hinsberg and Schumacher 2011). Such a feature is best shown by the spectacular, fine color banding in some pegmatitic tourmalines. Diffusional compositional adjustments may occur in tourmalines that are deformed at relatively high temperatures, probably through a dislocation-creep mechanism (Büttner 2005; Büttner and Kasemann 2007). Consequently, once a chemical signature is embedded in the tourmaline, it is preserved unless the tourmaline is deformed or is replaced by other minerals or other generations of tourmaline in response to reactive fluids (e.g. Dutrow and Henry 2000; Henry et al. 2004).

\subsubsection{Tourmaline as an active participant in chemical equilibria in rocks}

Tourmalines that form in igneous and metamorphic rocks typically develop chemical characteristics that reflect an approach to chemical equilibrium at various stages of development in the host rocks. This feature was initially demonstrated by Henry and Guidotti (1985) who showed that in near-isothermal staurolite-zone metapelitic rocks from NW Maine (USA), Mg-Fe and $\mathrm{Na}-\mathrm{Ca}$ partitioning form a systematic array between the rims of tourmaline and those of coexisting minerals, i.e. chemical equilibrium was approached. Thus, tourmaline has predictable and systematic element partitioning with other minerals in the rock. Table 1 presents examples of relative element partitioning for tourmaline coexisting with selected minerals. Such data provide general guidance as to tourmaline's chemical response in rock-buffered systems. Not surprisingly, B strongly partitions into tourmaline relative to coexisting minerals in most metapelitic rocks. However, $\mathrm{B}$ can be present in muscovite in minor, but significant, concentrations (e.g. $200 \mu \mathrm{g} / \mathrm{g}$, Henry and Dutrow 1996). Consequently, the breakdown of muscovite in metamorphic rocks can release $B$ to serve as an internal source of this element for growth of additional tourmaline (e.g. Henry and Dutrow 1996). Tourmaline also partitions $\mathrm{Mg}$, $\mathrm{Na}, \mathrm{F}$ and Co more effectively than the coexisting minerals chronicled in Tab. 1. In a somewhat counterintuitive manner, Li partitions into several other metamorphic pelitic minerals more effectively than tourmaline (e.g. Dutrow et al. 1986). Therefore, the formation of Li-rich tourmaline in these environments requires that the local rock system evolves in such a way that those minerals that more favorably partition Li are not present. Element-partitioning information continues to be determined and is now defined for a number of trace as well as major elements (van Hinsberg et al. 2017). Overall, these data imply that tourmaline is an active participant in evolving igneous and metamorphic rock systems (e.g. Henry and Dutrow 1996, 2001; Novák et al. 2011). However, in most instances tourmaline is an accessory or minor mineral that reflects the local chemical environment, but does not generally control it.

Because tourmaline can form at essentially all grades of metamorphism, the composition of the tourmaline 
crystallized at any given metamorphic stage reflects the local reactions and the element partitioning with coexisting minerals and fluids. Tourmaline that is formed at different stages is likely to be chemically responsive to the minerals and mineral compositions at each stage, and the tourmaline will become chemically zoned. This zoning can take on numerous forms, such as continuous growth zoning, oscillatory zoning or discontinuous zoning, reflecting dissolution and reprecipitation. The chemical responsiveness of tourmaline provides a general conceptual framework to interpret chemical zoning in tourmaline. However, as discussed subsequently, incorporation of elements on different faces may not be equivalent and this adds a level of complexity to the interpretation of chemical zoning (e.g. Lussier and Hawthorne 2011).

Where igneous and metamorphic fluids are reactive components of rock systems, tourmaline responds to changing fluid composition in a systematic and predictable manner such that transient fluid compositions can be recovered from the tourmaline chemistry (e.g. Henry and Dutrow 2012a; Dutrow and Henry 2016; van Hinsberg et al. 2017; Dutrow and Henry this volume). The implication is that tourmaline may provide the only chemical record of B-bearing fluids that pass through the rocks.

\subsubsection{Asymmetric growth, compositional polarity and sector zoning in tourmaline}

At low-to-moderate temperatures, up to $\sim 650^{\circ} \mathrm{C}$, tourmalines grow asymmetrically and disparate ions may be differentially incorporated on distinct tourmaline faces, i.e. the crystal can develop sector zoning (e.g. Henry and Dutrow 1996; Sperlich et al. 1996; van Hinsberg et al.

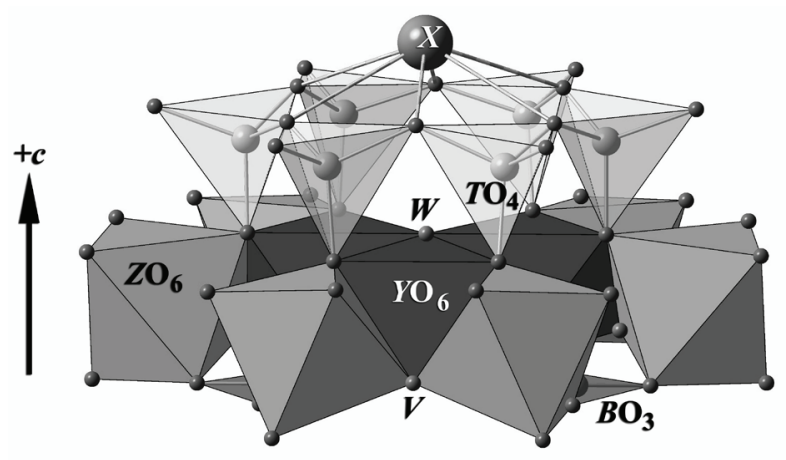

Fig. 3 Crystal-structure representation showing a portion of the tourmaline structure viewed perpendicular to the $c$-axis. Apices of the tetrahedra $\left(\mathrm{TO}_{4}\right)$ comprising the six-membered ring point in the same direction, $-c$, to produce the crystallographic asymmetry. Important polyhedra and sites are labelled. Octahedra, $\mathrm{YO}_{6}$ and $\mathrm{ZO}_{6}$, are shown together with the $\mathrm{BO}_{3}$ triangle and the $X, \mathrm{O}(1)$ and $\mathrm{O}(3)$ sites are located. This representation was generated using CrystalMaker ${ }^{\mathbb{B}}$ software.
2006). The asymmetric polar growth and compositional differences observed in tourmaline reflect its non-centrosymmetric nature $(R 3 m)$, with all of the apices of the $\mathrm{SiO}_{4}$ tetrahedra pointing toward the $-c$ pole of the crystal (Fig. 3). Electrically, this polar character is responsible for the pyroelectric and piezoelectric properties exhibited by tourmaline. Morphologically, this asymmetry is manifested in hemimorphically distinct faces at the $+c$ and $-c$ poles and, at relatively low temperatures, by preferential growth of tourmaline at the $+c$ pole (e.g. Dietrich 1985; Henry and Dutrow 1996). Chemically, this polarity is reflected by simultaneous incorporation of ions of different compositions at different tourmaline faces. Henry and Dutrow (1996) and Sperlich et al. (1996) described significant compositional differences between the $+c$ and $-c$-pyramidal faces (they termed - compositional polarity) for tourmalines that formed in low-temperature metasediments. For example, Henry and Dutrow (1996) noted that at chlorite-zone conditions $\left(\sim 450^{\circ} \mathrm{C}\right)$ in tourmaline grains with contemporaneous growth on different faces, $\mathrm{Al}$ and ${ }^{X} \square$ are preferentially incorporated at the pyramidal faces of the $+c$ pole whereas $\mathrm{Ca}, \mathrm{Na}$ and $\mathrm{Ti}$ are preferentially incorporated at the pyramidal faces of the $-c$ pole. These compositional differences diminish as metamorphic grade increases and disappear at roughly staurolite-zone conditions (Fig. 4). This differential interfacial element partitioning must be considered in petrologic studies involving tourmalines developed at moderate-to-low temperatures, particularly when dealing with intermineral element partitioning.

One of the more compelling applications of the temperature dependence exhibited by compositional polarity (sector zoning) is that it can be used to determine temperature during various growth stages of metamorphic tourmaline. Using the compositional polarity data of Henry and Dutrow (1996), van Hinsberg and Schumacher (2007a) developed an empirical intramineral elementpartitioning thermometer involving the sectors at $+c,-c$ and $a$ (the prismatic sector) of metamorphic tourmaline. Based on partitioning of $\mathrm{Ca}$ and $\mathrm{Ti}$ among these sectors, they quantified the thermometer for a range of temperatures (up to $\sim 650^{\circ} \mathrm{C}$ ). Thus, temperature histories can be recovered based on individual tourmaline grains spanning prograde, peak and retrograde metamorphic growth (e.g. van Hinsberg et al. 2011b).

\subsubsection{Detrital tourmaline as a provenance indicator in clastic sediments and sedimentary rocks}

Detrital tourmaline, a mechanically and chemically refractory heavy mineral likely present in most clastic sediments or sedimentary rocks, is a significant repository of information on the rock in which it originally 
formed and, consequently, the provenance of the clastic sediment. Using tourmaline data from the literature, Henry and Guidotti (1985) developed diagrams in the chemical subsystems $\mathrm{Al}-\mathrm{Fe}-\mathrm{Mg}$ and $\mathrm{Ca}-\mathrm{Fe}-\mathrm{Mg}$ to define regions diagnostic of specific source-rock types (Fig. 5). Consequently, based on a relative small amount of chemical data from detrital tourmaline grains, the host-rock environment/provenance can be constrained (e.g. Henry and Dutrow 1992). This approach has been used in provenance studies in over 150 publications.

\subsubsection{Ore deposits}

Prior to the Tourmaline 1997 Symposium, the common occurrence of tourmaline as a gangue mineral associated with ores was well known and tourmaline chemical character-

Fig. 4 Growth zoning of tourmaline in a staurolite-zone metapelite from NW Maine, USA. a - Schematic drawing of three generations of tourmaline growth zones developed on a detrital core (dc) from a staurolite-zone metapelite (see Fig. 9a in Henry and Dutrow 1996). The crystal is oriented parallel to the $c$-axis. Numbers represent the individual zones and white areas are quartz inclusions. Note the asymmetric growth of zones 1 and 2 preferentially toward the $+c$ direction of the crystal. b - Progressive compositional trajectories for each growth zone in terms of $\mathrm{Al}$ vs. $\mathrm{Mg} /(\mathrm{Mg}$ $+\mathrm{Fe}$ ). The direction and magnitude of the compositional zoning within the zone is indicated by solid arrows. Open symbols represent compositions at the $+c$ pole and closed symbols at the $-c$ pole. The zone- 1 analyses are squares, zone- 2 analyses are triangles and zone- 3 analyses are diamonds. The compositions of the overgrowths proximal to the detrital core are at the tail of the solid black arrows and represent a distinct difference between the + zone and - zone, i.e. compositional polarity. The zone- 2 arrows are significantly closer to each other and the -zone-3 analyses overlap. The directions of the compositional trends (arrows) are distinctly different between zones 1 and 2 and are interpreted as being a consequence of tourmaline growth associated with different metamorphic reactions at lower-grade metamorphism. The zone-3 analyses, interpreted as growth at staurolite-zone conditions, represent a complete convergence of polar compositions during the final stage of growth (modified after Henry and Dutrow 1996). istics were defined for many types of ore deposits (e.g. Slack 1980, 1996). Since that time, tourmaline-associated ore deposits have been a topic of sophisticated chemical and isotopic investigations, with particular focus on the interaction of tourmaline with fluids and its utility to define the evolution of ore-forming fluids (e.g. Slack and Turnbull 2011; Trumbull et al. 2011). Such work has shown that tourmaline may provide important information on ore-forming processes and ultimately may be developed as a useful prospecting tool.

\subsubsection{Tourmaline through geologic time}

Boron is considered the "quintessential crustal element" such that when it becomes available to the rock system, it
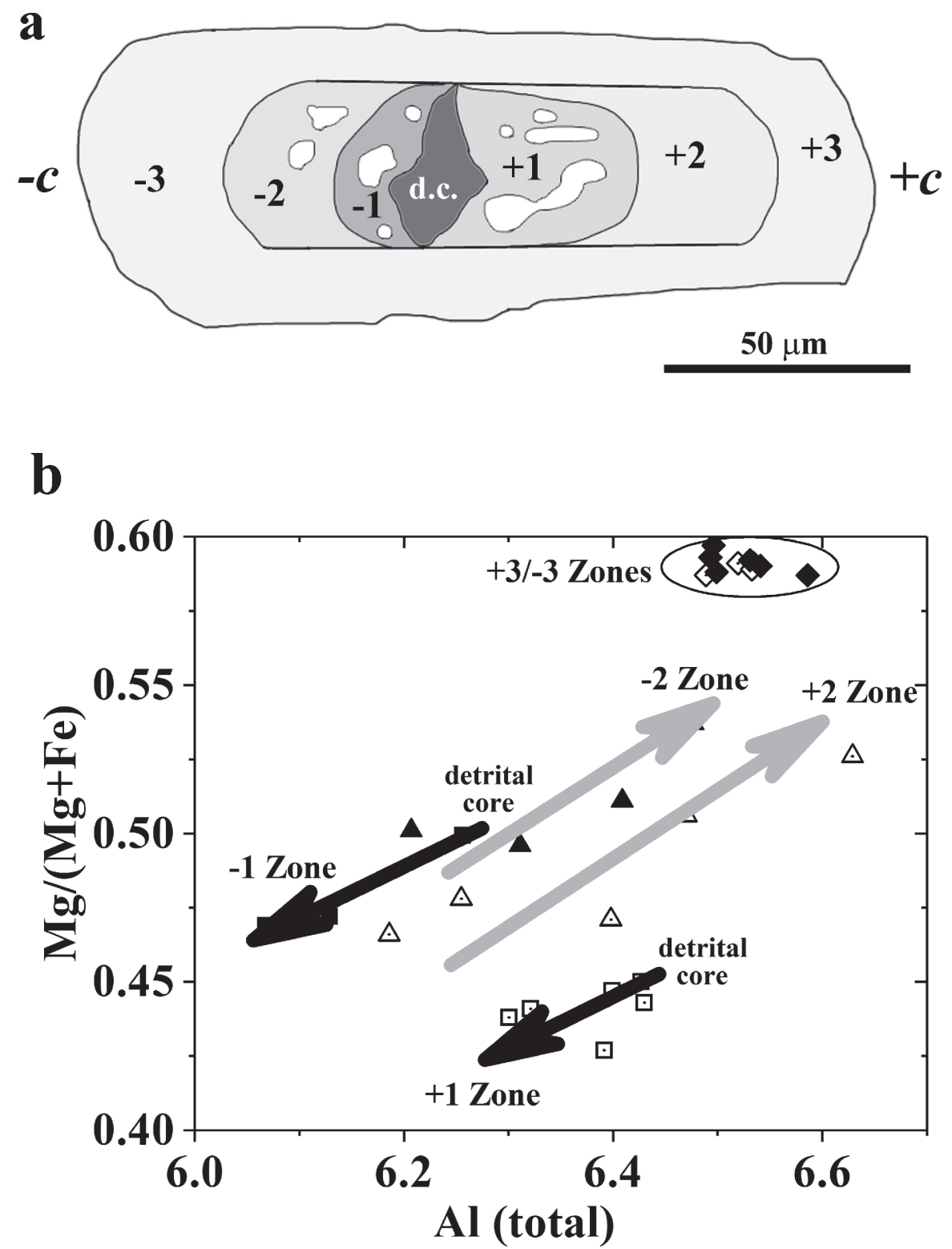


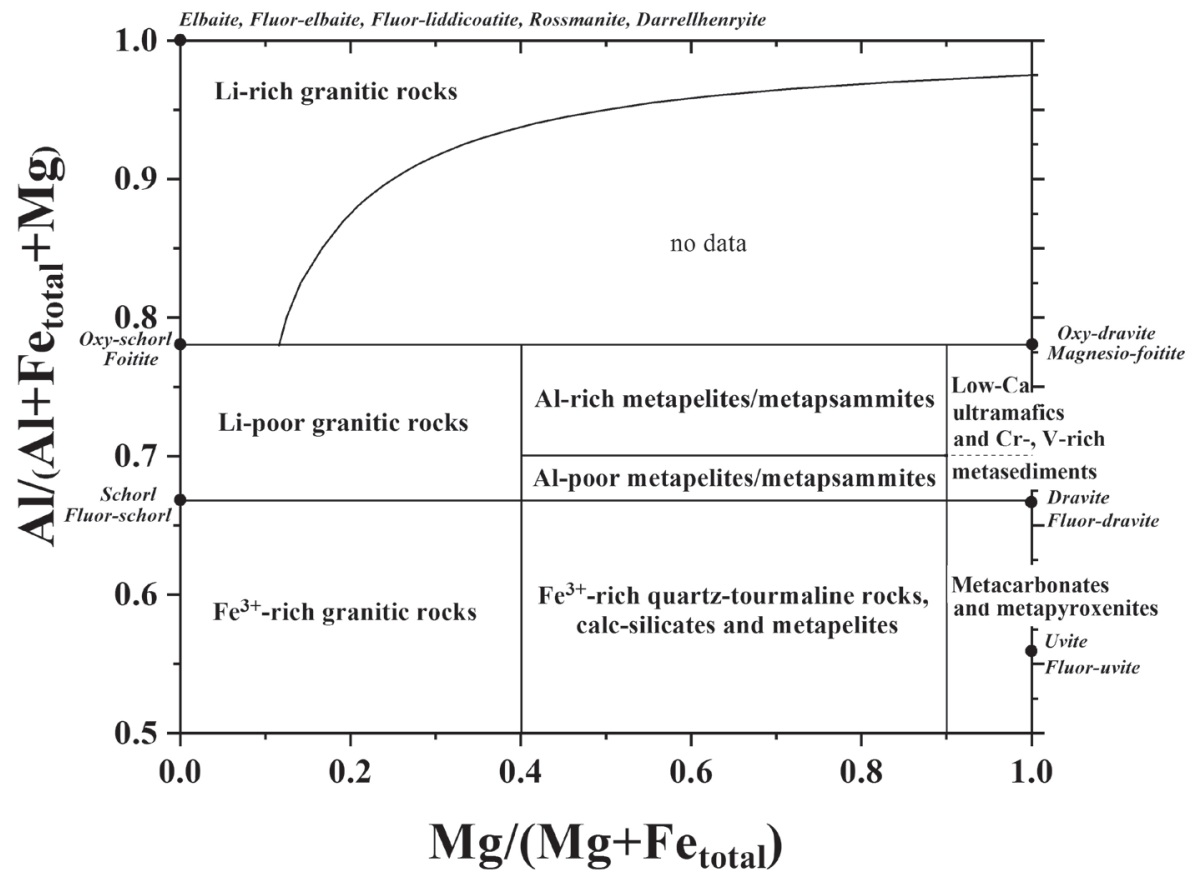

Fig. 5 Diagram correlating tourmaline compositions with source-rock type using the molar $\mathrm{Al}-\mathrm{Fe}-\mathrm{Mg}$ subsystem. This binary representation uses the original Henry and Guidotti (1985) data to define the rock-type boundaries. Italicized names represent locations of select tourmaline end-member species. is likely to form tourmaline under most crustal conditions (Grew 2017). Tourmaline is known to have been part of the rock record going back to at least the Eoarchean, as it is found in 3.7-3.8 Ga metasediments of the Isua Supracrustal Belt, Greenland (Boak and Dymek 1982; Grew et al. 2011; Mishima et al. 2016). Consequently, tourmaline is an important mineral throughout nearly the entire geologic record on Earth.

\subsubsection{Comprehensive metamorphic rock history from a single tourmaline}

With the advances in petrologic tourmaline studies over the last 20 years, it is now possible to define the entire evolutionary history (and prehistory) of a metamorphic rock with a tourmaline grain that incorporates and retains chemical and textural information at different stages of metamorphism. A particularly good illustration of such a petrologic approach was presented by van Hinsberg et al. (2011b) who traced developmental response of tourmaline though the geologic history of an evolving clastic metasedimentary rock cycle from (1) its initial crystallization in a hypothetical igneous environment and its later weathering and incorporation into a clastic sediment through (2) burial, subduction and prograde metamorphism to (3) retrograde metamorphism, uplift and erosion. Such an approach has been successfully applied in several studies that define the tectonic evolution of metamorphic rocks of, for example, the Haut-Allier region, Massif Central, France, and the Tauern Window in the eastern Alps (van Hinsberg and Schumacher 2011; Berryman et al. 2017).

\subsection{Crystallography, crystal chemistry and nomenclature of tourmaline}

Knowledge of the crystal chemistry of tourmaline has progressed significantly since 1977 and the structural formula has advanced accordingly. The general chemical formula of tourmaline was modified to $\mathrm{X} \mathrm{Y}_{3} \mathrm{Z}_{6}$ $\mathrm{Si}_{6}\left(\mathrm{BO}_{3}\right)_{3} \mathrm{O}_{18}(\mathrm{~V})_{3}(\mathrm{~W})$ where $\mathrm{X}=\mathrm{Na}, \mathrm{Ca}, \mathrm{K}$ or $\square$ (vacancy); $\mathrm{Y}=\mathrm{Al}, \mathrm{Li}, \mathrm{Fe}^{2+}, \mathrm{Mg}, \mathrm{Mn}^{2+}, \mathrm{Fe}^{3+}, \mathrm{V}^{3+}, \mathrm{Cr}^{3+}$, $\mathrm{Ti}^{4+} ; \mathrm{Z}=\mathrm{Al}, \mathrm{Mg}, \mathrm{Cr}^{3+}, \mathrm{V}^{3+}$ and $\mathrm{Fe}^{3+} ; \mathrm{T}=\mathrm{Si}, \mathrm{Al}, \mathrm{B} ; \mathrm{V}=$ $\mathrm{OH}^{-}, \mathrm{O}^{2-}$; and $\mathrm{W}=\mathrm{F}^{-}, \mathrm{O}^{2-}, \mathrm{OH}^{-}$(Hawthorne and Henry 1999). X, Y, Z, T and B represent groups of cations that occupy the $X, Y, Z, T$ and $B$ sites, respectively, in the $R 3 m$ tourmaline structure - note that the designated sites are italicized. The V-group anions occupy the $\mathrm{O}(3)$ anionic crystallographic site and the W-group anions the $\mathrm{O}(1)$ crystallographic site. The $\mathrm{H}$ ions occupy the $\mathrm{H} 1$ and $\mathrm{H} 3$ sites (e.g. Gatta et al. 2014).

Two developments significantly changed the way in which crystallography and crystal chemistry of tourmaline was considered and tourmaline is currently classified. Those are: (1) distinctions were made among the $\mathrm{O}(1)$ and $\mathrm{O}(3)$ anion sites, and (2) order-disorder phenomena involving cations across multiple cationic sites were demonstrated.

\subsubsection{Changing views of the $\mathrm{OH}$-bearing anion sites}

The OH-bearing sites, $\mathrm{O}(1)$ and $\mathrm{O}(3)$, are crystallographically distinct and the constituent anions of $\mathrm{OH}^{-}, \mathrm{O}^{2-}$ and $\mathrm{F}^{-}$order differently among these sites. The $\mathrm{O}(1)$ site 
exclusively contains all of the $\mathrm{F}^{-}$in tourmaline and preferentially incorporates $\mathrm{O}^{2-}$ relative to $\mathrm{OH}^{-}$(e.g. Robert 1992). The $\mathrm{O}(3)$ site is typically dominated by $\mathrm{OH}^{-}$, but can be occupied by dominant $\mathrm{O}^{2-}$, although this is less common. Thus, there are two distinct $\mathrm{OH}$-bearing anion sites and they can each have different anion dominance i.e. $\mathrm{OH}^{-}, \mathrm{O}^{2-}$ or $\mathrm{F}^{-}$at the $\mathrm{O}(1)$ site and $\mathrm{OH}^{-}$ or $\mathrm{O}^{2-}$ dominance at the $\mathrm{O}(3)$ site. Each of these variants justifies a series of new tourmaline species (Hawthorne and Henry 1999; Henry et al. 2011).

\subsubsection{Order-disorder in tourmaline}

Local bond-valence requirements mandate that only certain short-range arrangements are stable (Hawthorne et al. 1993). Order-disorder reactions may be operative and these will control the actual position of cations in the tourmaline structure (e.g. Hawthorne 1996). This feature is most acute where $\mathrm{O}^{2-}$ is located at the $\mathrm{O}(1)$ site, e.g. in Li-poor tourmalines, where $\mathrm{Mg}$ is typically disordered at the $Z$ site (up to $2 \mathrm{Mg}$ apfu) and $\mathrm{Al}$ at the $Y$ site with the local arrangement of

Fig. 6 Ternary systems for primary groups used for general tourmaline-species designation (modified after Henry et al. 2011). a - Ternary system for the primary-tourmaline groups based on the dominant occupancy of the $X$ site. Note that alkaligroup tourmaline can be $\mathrm{Na}$ - or K-dominant. b - Ternary system for a general tourmaline series based on the anion occupancy of the $\mathrm{O}(1)$ site $(\equiv \mathrm{W}$ anions). Note that the anions are either $2-\left(\mathrm{O}^{2-}\right)$ or $1-\left(\mathrm{OH}^{-}\right.$or $\left.\mathrm{F}^{-}\right)$such that oxy species require more than $50 \%$ $\mathrm{O}^{2-}$ occupancy at this site.

a

\section{Tourmaline primary groups $-X$-site}

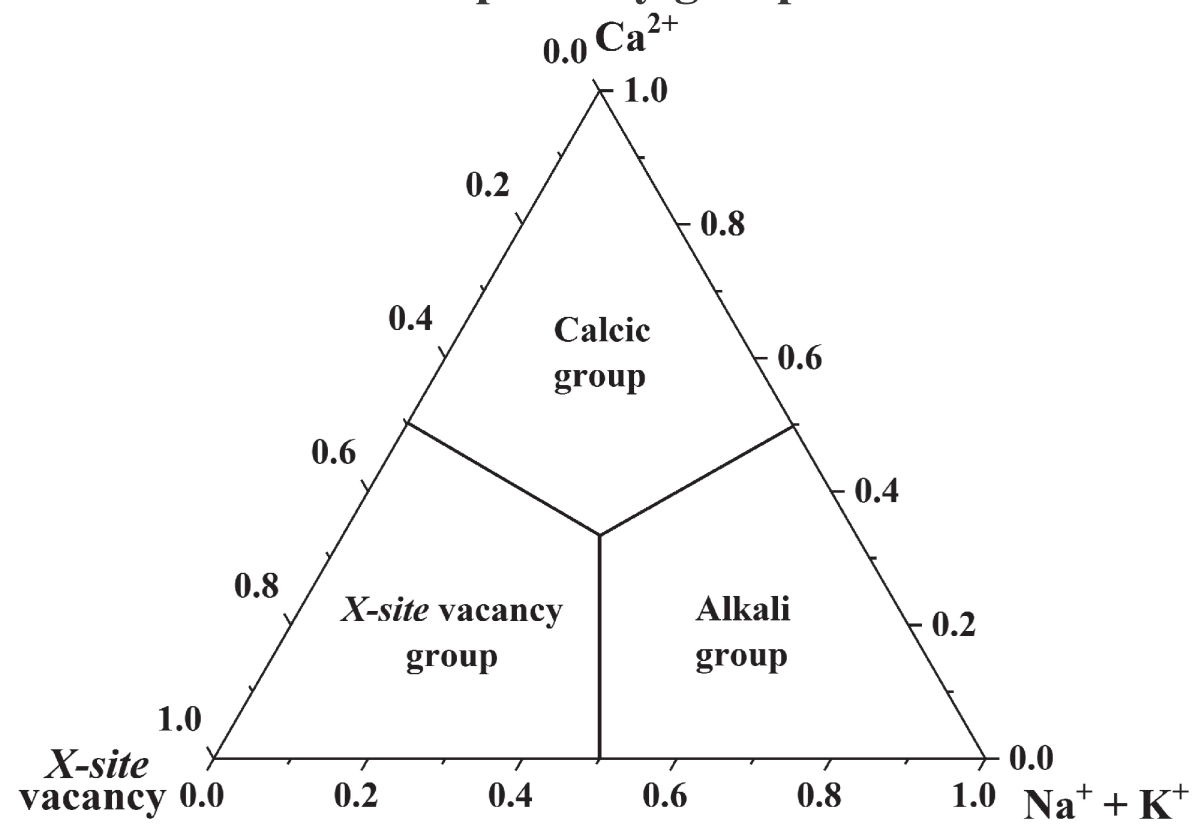

General tourmaline species - O(1)-site (W anions)

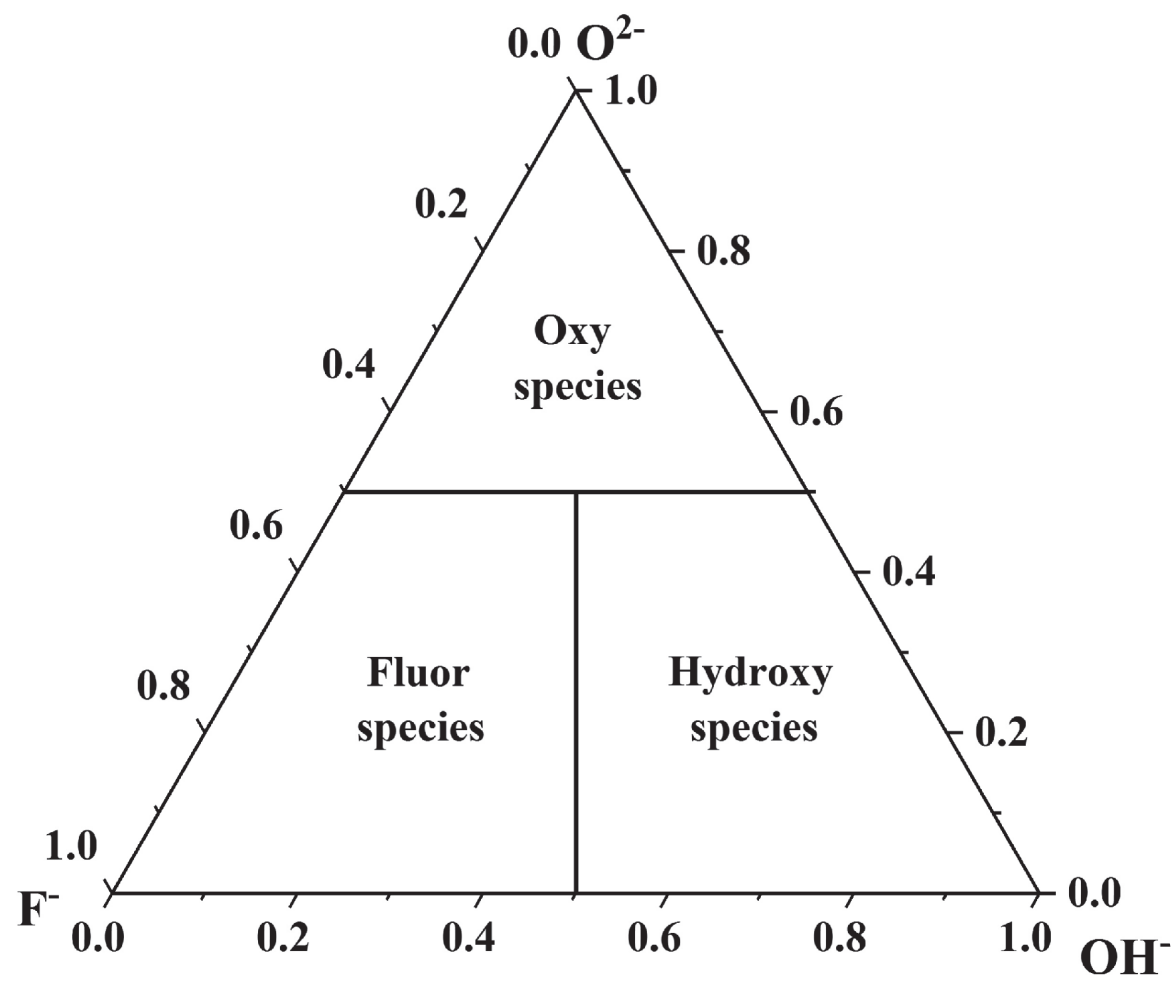


Dunn 1979). Ferridravite was subsequently found to exhibit significant amounts of $\mathrm{Mg}$ at the $Z$ site, and this led to the redefinition and its renaming as a new species, povondraite (Grice and Ercit 1993; Grice et al. 1993). Although only one example is presented here, order-disorder is a significant consideration in tourmaline-species definitions.

\subsubsection{Tourmaline species and classification schemes}

With the new crystallographic constraints in place, a robust means of classification for tourmaline-group minerals became possible. Hawthorne and Henry (1999) proposed a preliminary tourmaline-classification scheme that included the general structural formula presented above and applied the new crystallographic restrictions. They suggested that tourmaline should be divided into three primary groups based on the dominant occupancy of the $X$ site, the alkali group ( $\mathrm{Na}$ or $\mathrm{K}$ ), the calcic group, and the $X$-site vacant group (Fig. 6a). Further, they suggested that the dominant anions at the $\mathrm{OH}$-bearing sites, $\mathrm{O}(1)[\equiv \mathrm{W}$ anions $]$ and $\mathrm{O}(3)[\equiv \mathrm{V}$ anions], form the basis for additional secondary groups (Fig. 6b). At that time, the number of accepted tourmaline species increased to 13 (Fig 2).

A more thorough investigation of tourmaline nomenclature occurred with the formation of the Subcommittee on Tourmaline Nomenclature (STN), chaired by Milan Novák. The STN ultimately published an IMA-CNMNCapproved nomenclature for tourmaline minerals now recognized as a supergroup (Henry et al. 2011). In this comprehensive assessment, tourmaline is considered a supergroup mineral because it contains multiple mineral groups, but all have the same structure and are chemically similar minerals, i.e. the three $X$-site-based primary groups (Fig. 6a). A guideline used to define tourmaline species was the dominant-valency rule; it states that in a relevant site the dominant ion of the dominant valence state is used for nomenclature purposes (Hatert and Burke 2008). A relevant application of this rule is represented by the ternary diagram defining secondary groups related to the $\mathrm{O}(1)$ site ( $\equiv \mathrm{W}$ anions), i.e. hydroxyl-, fluor- and oxy-species tourmalines (Fig. 6b). An additional consideration, termed valency-imposed double-site occupancy, occurs where heterovalent coupled substitutions take place at single or multiple sites such that end-members are produced in which two ions occupy a single site e.g. elbaite $\left(\mathrm{Li}^{+}{ }_{1.5} \mathrm{Al}^{3+}{ }_{1.5}\right.$ in the $\mathrm{Y}$ site). With these considerations in place, the number of tourmaline species has increased greatly and now includes 33 species (Fig. 2). Table 2 gives the currently accepted tourmaline species organized such that each primary group is further subdi- vided into a series of convenient subspecies that have a common generic formula.

Another aspect of the nomenclature effort was to develop graphical representations to express the important substitutional mechanisms in tourmaline and to provide a general method to classify and visualize multicomponent tourmaline compositions (Henry et al. 2011). Two examples, given in Fig. 7, are the $\mathrm{Fe}-\mathrm{Mg}-2 \mathrm{Li}$ ternary for alkali-group, aluminous hydroxy-tourmaline species and the ${ }^{Y Z} \mathrm{R}^{2+} /\left({ }^{Y Z} \mathrm{R}^{2+}+2 \mathrm{Li}\right)$ vs. $\mathrm{Ca} /(\mathrm{Ca}+\mathrm{Na}+\mathrm{K})$ diagram for aluminous tourmalines with low ${ }^{X} \square$. Recently, a series of studies have expanded the number of $\mathrm{Cr}$ - and V-bearing oxy-species and these compositions created a need for additional diagrams (e.g. Bosi et al. 2012, 2014, 2017; Bačík et al. 2013; Reznitskii et al. 2014). Based on the amount of $\mathrm{Cr}, \mathrm{V}, \mathrm{Al}$ and $\mathrm{Fe}^{3+}$ cations at the combined $Y$ and $Z$ sites for each of the end-member species, an updated set of classification diagrams is generated for sodic oxy-tourmalines that contain significant amounts of $\mathrm{Cr}$, $\mathrm{V}$ and $\mathrm{Fe}^{3+}$ (Fig. 8).

\subsubsection{Tourmaline trace elements}

With the increasingly common measurements of trace elements in tourmaline at the micrometer scale, these elements have become important tracers of the evolution of the rocks and fluids interacting with tourmaline. A few examples follow. Ratios of $\mathrm{Ba}, \mathrm{Th}, \mathrm{La}$ and $\mathrm{Sm}$ in tourmaline have been used to model subduction-zone fluids and their impact on arc-magmatism signatures (van Hinsberg et al. 2017). Trace amounts of $\mathrm{Sr}, \mathrm{Sc}, \mathrm{V}, \mathrm{Ni}, \mathrm{Pb}, \mathrm{Zr}$, Ta, $\mathrm{Nb}, \mathrm{Cr}, \mathrm{Ga}$ and $\mathrm{Sn}$ and rare-earth elements in tourmaline have been used as proxies for mineralizing fluids in ore deposits and in other rock environments (e.g. Duchoslav et al. 2017; Hazarika et al. 2017; Hong et al. 2017; Kalliomäki et al 2017). Chlorine contents in tourmaline are used to establish the unusual hydrothermal setting for altered dioritic porphyries associated with a gold deposit (Bačík et al. 2015).

\subsection{Isotope geochemistry and geochronology}

Prior to the Tourmaline 1997 Symposium, much of the isotopic work involved bulk-mineral $\mathrm{B}, \mathrm{O}, \mathrm{H}$ isotopes on tourmaline and coexisting minerals to make inferences on topics such as formation temperatures or fluid sources (e.g. Palmer 1991; Kotzer et al. 1993). With improved instrumentation and in situ analytical techniques (e.g. SIMS), isotopic information on tourmaline has been gathered with higher spatial resolution for a greater array of isotopic systems: $\mathrm{B}, \mathrm{O}, \mathrm{H}, \mathrm{Si}, \mathrm{Mg}, \mathrm{Li}, \mathrm{Sr}, \mathrm{Nd}, \mathrm{Pb}, \mathrm{K}(\mathrm{Ar})$ and $\mathrm{Cu}$ (e.g. Marschall and Jiang 2011). This wide range of isotopic possibilities has many potential and intrigu- 
Tab. 2 IMA-CMNMC-approved tourmaline species (as of December, 2017)

\begin{tabular}{|c|c|c|c|c|c|c|c|}
\hline General formula: & $(\mathrm{X})$ & $\left(\mathbf{Y}_{3}\right)$ & $\left(\mathrm{Z}_{6}\right)$ & $\mathbf{T}_{6} \mathbf{O}_{18}$ & $\left(\mathrm{BO}_{3}\right)_{3}$ & $(\mathrm{~V})_{3}$ & $(\mathbf{W})$ \\
\hline \multicolumn{8}{|c|}{ Alkali group species (23 species) } \\
\hline Subgroup 1 & $* \mathbf{R}^{1+}$ & $\mathbf{R}_{3}^{2+}$ & $\mathbf{R}_{6}^{3+}$ & $\mathbf{R}_{6}^{4+} \mathbf{O}_{18}$ & $\left(\mathrm{BO}_{3}\right)_{3}$ & $* * \mathbf{S}_{3}^{1-}$ & $\mathbf{S}^{1-}$ \\
\hline Dravite & $\mathrm{Na}$ & $\mathrm{Mg}_{3}$ & $\mathrm{Al}_{6}$ & $\mathrm{Si}_{6} \mathrm{O}_{18}$ & $\left(\mathrm{BO}_{3}\right)_{3}$ & $(\mathrm{OH})_{3}$ & $(\mathrm{OH})$ \\
\hline Fluor-dravite & $\mathrm{Na}$ & $\mathrm{Mg}_{3}$ & $\mathrm{Al}_{6}$ & $\mathrm{Si}_{6} \mathrm{O}_{18}$ & $\left(\mathrm{BO}_{3}\right)_{3}$ & $(\mathrm{OH})_{3}$ & (F) \\
\hline Schorl & $\mathrm{Na}$ & $\mathrm{Fe}^{2+}{ }_{3}$ & $\mathrm{Al}_{6}$ & $\mathrm{Si}_{6} \mathrm{O}_{18}$ & $\left(\mathrm{BO}_{3}\right)_{3}$ & $(\mathrm{OH})_{3}$ & $(\mathrm{OH})$ \\
\hline Fluor-schorl & $\mathrm{Na}$ & $\mathrm{Fe}_{3}^{2+}$ & $\mathrm{Al}_{6}$ & $\mathrm{Si}_{6} \mathrm{O}_{18}$ & $\left(\mathrm{BO}_{3}\right)_{3}$ & $(\mathrm{OH})_{3}$ & (F) \\
\hline Tsilaisite & $\mathrm{Na}$ & $\mathrm{Mn}_{3}^{2+}$ & $\mathrm{Al}_{6}$ & $\mathrm{Si}_{6} \mathrm{O}_{18}$ & $\left(\mathrm{BO}_{3}\right)_{3}$ & $(\mathrm{OH})_{3}$ & $(\mathrm{OH})$ \\
\hline Fluor-tsilaisite & $\mathrm{Na}$ & $\mathrm{Mn}_{3}^{2+}$ & $\mathrm{Al}_{6}$ & $\mathrm{Si}_{6} \mathrm{O}_{18}$ & $\left(\mathrm{BO}_{3}\right)_{3}$ & $(\mathrm{OH})_{3}$ & (F) \\
\hline Chromium-dravite & $\mathrm{Na}$ & $\mathrm{Mg}_{3}$ & $\mathrm{Cr}_{6}$ & $\mathrm{Si}_{6} \mathrm{O}_{18}$ & $\left(\mathrm{BO}_{3}\right)_{3}$ & $(\mathrm{OH})_{3}$ & $(\mathrm{OH})$ \\
\hline Vanadium-dravite & $\mathrm{Na}$ & $\mathrm{Mg}_{3}$ & $\mathrm{~V}_{6}$ & $\mathrm{Si}_{6} \mathrm{O}_{18}$ & $\left(\mathrm{BO}_{3}\right)_{3}$ & $(\mathrm{OH})_{3}$ & $(\mathrm{OH})$ \\
\hline Subgroup 2 & $\mathbf{R}^{1+}$ & $\mathbf{R}^{1+}{ }_{1.5} \mathbf{R}^{3+}{ }_{1.5}$ & $\mathbf{R}_{6}^{3+}$ & $\mathbf{R}_{6}^{4+} \mathbf{O}_{18}$ & $\left(\mathrm{BO}_{3}\right)_{3}$ & $\mathbf{S}_{3}^{1-}$ & $\mathbf{S}^{1-}$ \\
\hline Elbaite & $\mathrm{Na}$ & $\mathrm{Li}_{1.5} \mathrm{Al}_{1.5}$ & $\mathrm{Al}_{6}$ & $\mathrm{Si}_{6} \mathrm{O}_{18}$ & $\left(\mathrm{BO}_{3}\right)_{3}$ & $(\mathrm{OH})_{3}$ & $(\mathrm{OH})$ \\
\hline Fluor-elbaite & $\mathrm{Na}$ & $\mathrm{Li}_{1.5} \mathrm{Al}_{1.5}$ & $\mathrm{Al}_{6}$ & $\mathrm{Si}_{6} \mathrm{O}_{18}$ & $\left(\mathrm{BO}_{3}\right)_{3}$ & $(\mathrm{OH})_{3}$ & (F) \\
\hline Subgroup 3 (Y-Z order/disorder) & $\mathbf{R}^{1+}$ & $\mathbf{R}_{3}^{3+}$ to $\mathbf{R}_{2}^{2+} \mathbf{R}^{3+}$ & $\mathbf{R}^{3+}{ }_{4} \mathbf{R}_{2}^{2+}$ to $\mathbf{R}^{3+}{ }_{6}$ & ${ }_{6} \mathbf{R}_{6}^{4+} \mathbf{O}_{18}$ & $\left(\mathrm{BO}_{3}\right)_{3}$ & $\mathbf{S}_{3}^{1-}$ & $\mathbf{S}^{2-}$ \\
\hline Oxy-dravite & $\mathrm{Na}$ & $\mathrm{Al}_{2} \mathrm{Mg}$ & $\mathrm{Al}_{5} \mathrm{Mg}$ & $\mathrm{Si}_{6} \mathrm{O}_{18}$ & $\left(\mathrm{BO}_{3}\right)_{3}$ & $(\mathrm{OH})_{3}$ & (O) \\
\hline Oxy-schorl & $\mathrm{Na}$ & $\mathrm{Fe}^{2+}{ }_{2} \mathrm{Al}$ & $\mathrm{Al}_{6}$ & $\mathrm{Si}_{6} \mathrm{O}_{18}$ & $\left(\mathrm{BO}_{3}\right)_{3}$ & $(\mathrm{OH})_{3}$ & (O) \\
\hline Povondraite & $\mathrm{Na}$ & $\mathrm{Fe}_{3}^{3+}$ & $\mathrm{Fe}^{3+}{ }_{4} \mathrm{Mg}_{2}$ & $\mathrm{Si}_{6} \mathrm{O}_{18}$ & $\left(\mathrm{BO}_{3}\right)_{3}$ & $(\mathrm{OH})_{3}$ & $(\mathrm{O})$ \\
\hline Bosiite & $\mathrm{Na}$ & $\mathrm{Fe}^{3+}{ }_{3}$ & $\mathrm{Al}_{4} \mathrm{Mg}_{2}$ & $\mathrm{Si}_{6} \mathrm{O}_{18}$ & $\left(\mathrm{BO}_{3}\right)_{3}$ & $(\mathrm{OH})_{3}$ & $(\mathrm{O})$ \\
\hline Chromo-alumino-povondraite & $\mathrm{Na}$ & $\mathrm{Cr}_{3}$ & $\mathrm{Al}_{4} \mathrm{Mg}_{2}$ & $\mathrm{Si}_{6} \mathrm{O}_{18}$ & $\left(\mathrm{BO}_{3}\right)_{3}$ & $(\mathrm{OH})_{3}$ & $(\mathrm{O})$ \\
\hline Oxy-chromium dravite & $\mathrm{Na}$ & $\mathrm{Cr}_{3}$ & $\mathrm{Cr}_{4} \mathrm{Mg}_{2}$ & $\mathrm{Si}_{6} \mathrm{O}_{18}$ & $\left(\mathrm{BO}_{3}\right)_{3}$ & $(\mathrm{OH})_{3}$ & $(\mathrm{O})$ \\
\hline Oxy-vanadium dravite & $\mathrm{Na}$ & $\mathrm{V}_{3}$ & $\mathrm{~V}_{4} \mathrm{Mg}_{2}$ & $\mathrm{Si}_{6} \mathrm{O}_{18}$ & $\left(\mathrm{BO}_{3}\right)_{3}$ & $(\mathrm{OH})_{3}$ & (O) \\
\hline Vanadio-oxy-chromium dravite & $\mathrm{Na}$ & $\mathrm{V}_{3}$ & $\mathrm{Cr}_{4} \mathrm{Mg}_{2}$ & $\mathrm{Si}_{6} \mathrm{O}_{18}$ & $\left(\mathrm{BO}_{3}\right)_{3}$ & $(\mathrm{OH})_{3}$ & (O) \\
\hline Vanadio-oxy-dravite & $\mathrm{Na}$ & $\mathrm{V}_{3}$ & $\mathrm{Al}_{4} \mathrm{Mg}_{2}$ & $\mathrm{Si}_{6} \mathrm{O}_{18}$ & $\left(\mathrm{BO}_{3}\right)_{3}$ & $(\mathrm{OH})_{3}$ & $(\mathrm{O})$ \\
\hline Maruyamaite & $\mathrm{K}$ & $\mathrm{MgAl}_{2}$ & $\mathrm{Al}_{5} \mathrm{Mg}$ & $\mathrm{Si}_{6} \mathrm{O}_{18}$ & $\left(\mathrm{BO}_{3}\right)_{3}$ & $(\mathrm{OH})_{3}$ & $(\mathrm{O})$ \\
\hline Subgroup 4 & $\mathbf{R}^{1+}$ & $\mathbf{R}^{1+} \mathbf{R}^{3+}{ }_{2}$ & $\mathbf{R}_{6}^{3+}$ & $\mathbf{R}_{6}^{4+} \mathbf{O}_{18}$ & $\left(\mathrm{BO}_{3}\right)_{3}$ & $\mathbf{S}_{3}^{1-}$ & $\mathbf{S}^{2-}$ \\
\hline Darrellhenryite & $\mathrm{Na}$ & $\mathrm{LiAl}_{2}$ & $\mathrm{Al}_{6}$ & $\mathrm{Si}_{6} \mathrm{O}_{18}$ & $\left(\mathrm{BO}_{3}\right)_{3}$ & $(\mathrm{OH})_{3}$ & $(\mathrm{O})$ \\
\hline Subgroup 5 & $\mathbf{R}^{1+}$ & $\mathbf{R}_{3}^{3+}$ & $\mathbf{R}_{6}^{3+}$ & $\mathbf{R}_{6}^{4+} \mathbf{O}_{18}$ & $\left(\mathrm{BO}_{3}\right)_{3}$ & $\mathrm{~S}_{3}^{2-}$ & $\mathbf{S}^{1-}$ \\
\hline Olenite & $\mathrm{Na}$ & $\mathrm{Al}_{3}$ & $\mathrm{Al}_{6}$ & $\mathrm{Si}_{6} \mathrm{O}_{18}$ & $\left(\mathrm{BO}_{3}\right)_{3}$ & $(\mathrm{O})_{3}$ & $(\mathrm{OH})$ \\
\hline Fluor-buergerite & $\mathrm{Na}$ & $\mathrm{Fe}_{3}^{3+}$ & $\mathrm{Al}_{6}$ & $\mathrm{Si}_{6} \mathrm{O}_{18}$ & $\left(\mathrm{BO}_{3}\right)_{3}$ & $(\mathrm{O})_{3}$ & $(\mathrm{~F})$ \\
\hline \multicolumn{8}{|c|}{ Calcic group species (6 species) } \\
\hline Subgroup 1 & $\mathbf{R}^{2+}$ & $\mathbf{R}_{3}^{2+}$ & $\mathbf{R}^{3+}{ }_{5} \mathbf{R}^{2+}$ & $\mathbf{R}_{6}^{4+} \mathbf{O}_{18}$ & $\left(\mathrm{BO}_{3}\right)_{3}$ & $\mathbf{S}_{3}^{1-}$ & $\mathbf{S}^{1-}$ \\
\hline Uvite & $\mathrm{Ca}$ & $\mathrm{Mg}_{3}$ & $\mathrm{Al}_{5} \mathrm{Mg}$ & $\mathrm{Si}_{6} \mathrm{O}_{18}$ & $\left(\mathrm{BO}_{3}\right)_{3}$ & $(\mathrm{OH})_{3}$ & $(\mathrm{OH})$ \\
\hline Fluor-dravite & $\mathrm{Ca}$ & $\mathrm{Mg}_{3}$ & $\mathrm{Al}_{5} \mathrm{Mg}$ & $\mathrm{Si}_{6} \mathrm{O}_{18}$ & $\left(\mathrm{BO}_{3}\right)_{3}$ & $(\mathrm{OH})_{3}$ & (F) \\
\hline Feruvite & $\mathrm{Ca}$ & $\mathrm{Fe}_{3}^{2+}$ & $\mathrm{Al}_{5} \mathrm{Mg}$ & $\mathrm{Si}_{6} \mathrm{O}_{18}$ & $\left(\mathrm{BO}_{3}\right)_{3}$ & $(\mathrm{OH})_{3}$ & $(\mathrm{OH})$ \\
\hline Subgroup 2 & $\mathbf{R}^{2+}$ & $\mathbf{R}^{1+}{ }_{2} \mathbf{R}^{3+}$ & $\mathbf{R}^{3+}{ }_{6}$ & $\mathbf{R}_{6}^{4+} \mathbf{O}_{18}$ & $\left(\mathrm{BO}_{3}\right)_{3}$ & $\mathbf{S}_{3}^{1-}$ & $\mathbf{S}^{1-}$ \\
\hline Fluor-liddicoatite & $\mathrm{Ca}$ & $\mathrm{Li}_{2} \mathrm{Al}$ & $\mathrm{Al}_{6}$ & $\mathrm{Si}_{6} \mathrm{O}_{18}$ & $\left(\mathrm{BO}_{3}\right)_{3}$ & $(\mathrm{OH})_{3}$ & $(\mathrm{~F})$ \\
\hline Subgroup 3 & $\mathbf{R}^{2+}$ & $\mathbf{R}_{3}^{2+}$ & $\mathbf{R}^{3+}{ }_{6}$ & $\mathbf{R}_{6}^{4+} \mathbf{O}_{18}$ & $\left(\mathrm{BO}_{3}\right)_{3}$ & $\mathrm{~S}_{3}^{1-}$ & $\mathbf{S}^{2-}$ \\
\hline Lucchesiite & $\mathrm{Ca}$ & $\mathrm{Fe}_{3}^{2+}$ & $\mathrm{Al}_{6}$ & $\mathrm{Si}_{6} \mathrm{O}_{18}$ & $\left(\mathrm{BO}_{3}\right)_{3}$ & $(\mathrm{OH})_{3}$ & $(\mathrm{O})$ \\
\hline Subgroup 4 & $\mathbf{R}^{2+}$ & $\mathbf{R}_{3}^{2+}$ & $\mathbf{R}^{3+}{ }_{6}$ & $\mathbf{R}^{4+}{ }_{5} \mathbf{R}^{3+} \mathbf{O}_{18}$ & $\left(\mathrm{BO}_{3}\right)_{3}$ & $\mathbf{S}_{3}^{1-}$ & $\mathbf{S}^{1-}$ \\
\hline Adachiite & $\mathrm{Ca}$ & $\mathrm{Fe}_{3}^{2+}$ & $\mathrm{Al}_{6}$ & $\mathrm{Si}_{5} \mathrm{AlO}_{18}$ & $\left(\mathrm{BO}_{3}\right)_{3}$ & $(\mathrm{OH})_{3}$ & $(\mathrm{OH})$ \\
\hline \multicolumn{8}{|c|}{ X-site vacant group species (4 species) } \\
\hline Subgroup 1 & $\square^{* * *}$ & $\mathbf{R}^{2+} \mathbf{R}^{3+}{ }_{2}$ & $\mathrm{R}^{3+}{ }_{6} \quad \mathrm{I}$ & $\mathbf{R}_{6}^{4+} \mathbf{O}_{18}$ & $\left(\mathrm{BO}_{3}\right)_{3}$ & $\mathrm{~S}_{3}^{1-}$ & $\mathbf{S}^{1-}$ \\
\hline Magnesio-foitite & $\square$ & $\mathrm{Mg}_{2} \mathrm{Al}$ & $\mathrm{Al}_{6}$ & $\mathrm{Si}_{6} \mathrm{O}_{18}$ & $\left(\mathrm{BO}_{3}\right)_{3}$ & $(\mathrm{OH})_{3}$ & $(\mathrm{OH})$ \\
\hline Foitite & $\square$ & $\mathrm{Fe}^{2+}{ }_{2} \mathrm{Al}$ & $\mathrm{Al}_{6}$ & $\mathrm{Si}_{6} \mathrm{O}_{18}$ & $\left(\mathrm{BO}_{3}\right)_{3}$ & $(\mathrm{OH})_{3}$ & $(\mathrm{OH})$ \\
\hline Subgroup 2 & $\square$ & $\mathbf{R}^{1+} \mathbf{R}^{3+}{ }_{2}$ & $\mathbf{R}^{3+}{ }_{6}$ & $\mathbf{R}_{6}^{4+} \mathbf{O}_{18}$ & $\left(\mathrm{BO}_{3}\right)_{3}$ & $\mathrm{~S}_{3}^{1-}$ & $\mathbf{S}^{1-}$ \\
\hline Rossmanite & $\square$ & $\mathrm{Li} \mathrm{Al}_{2}$ & $\mathrm{Al}_{6}$ & $\mathrm{Si}_{6} \mathrm{O}_{18}$ & $\left(\mathrm{BO}_{3}\right)_{3}$ & $(\mathrm{OH})_{3}$ & $(\mathrm{OH})$ \\
\hline Subgroup 3 & $\square$ & $\mathbf{R}^{1+} \mathbf{R}^{3+}{ }_{2}$ & $\mathbf{R}^{3+}{ }_{6}$ & $\mathbf{R}_{6}^{4+} \mathbf{O}_{18}$ & $\left(\mathrm{BO}_{3}\right)_{3}$ & $\mathrm{~S}_{3}^{1-}$ & $\mathrm{S}^{2-}$ \\
\hline Oxy-foitite & $\square$ & $\mathrm{Fe}^{2+}{ }_{2} \mathrm{Al}$ & $\mathrm{Al}_{6}$ & $\mathrm{Si}_{6} \mathrm{O}_{18}$ & $\left(\mathrm{BO}_{3}\right)_{3}$ & $(\mathrm{OH})_{3}$ & (O) \\
\hline
\end{tabular}

* $\mathrm{R}$ is a generic designation of a cation of the indicated charge

** $\mathrm{S}$ is a generic designation of an anion of the indicated charge

$* * * \mathrm{X}$-site vacancy $\square$ 
ing applications; for instance, provenance for some gem tourmalines can be deciphered.

One of the areas of isotope studies, in the nascent stages, is related to geochronology using tourmaline. The geological utility includes, for example, an investigation of ${ }^{206} \mathrm{~Pb} /{ }^{204} \mathrm{~Pb}$ to identify the time of tourmaline formation relative to the metamorphic and subsequent deformational events (Duncan et al. 2006). Geologically meaningful

\section{a Alkali group - $\mathrm{Li}_{-} \mathrm{Fe}^{2+}-\mathrm{Mg}_{-}{ }^{Z} \mathrm{Al}-{ }^{\mathrm{O}(1)}(\mathrm{OH})$ subsystem}

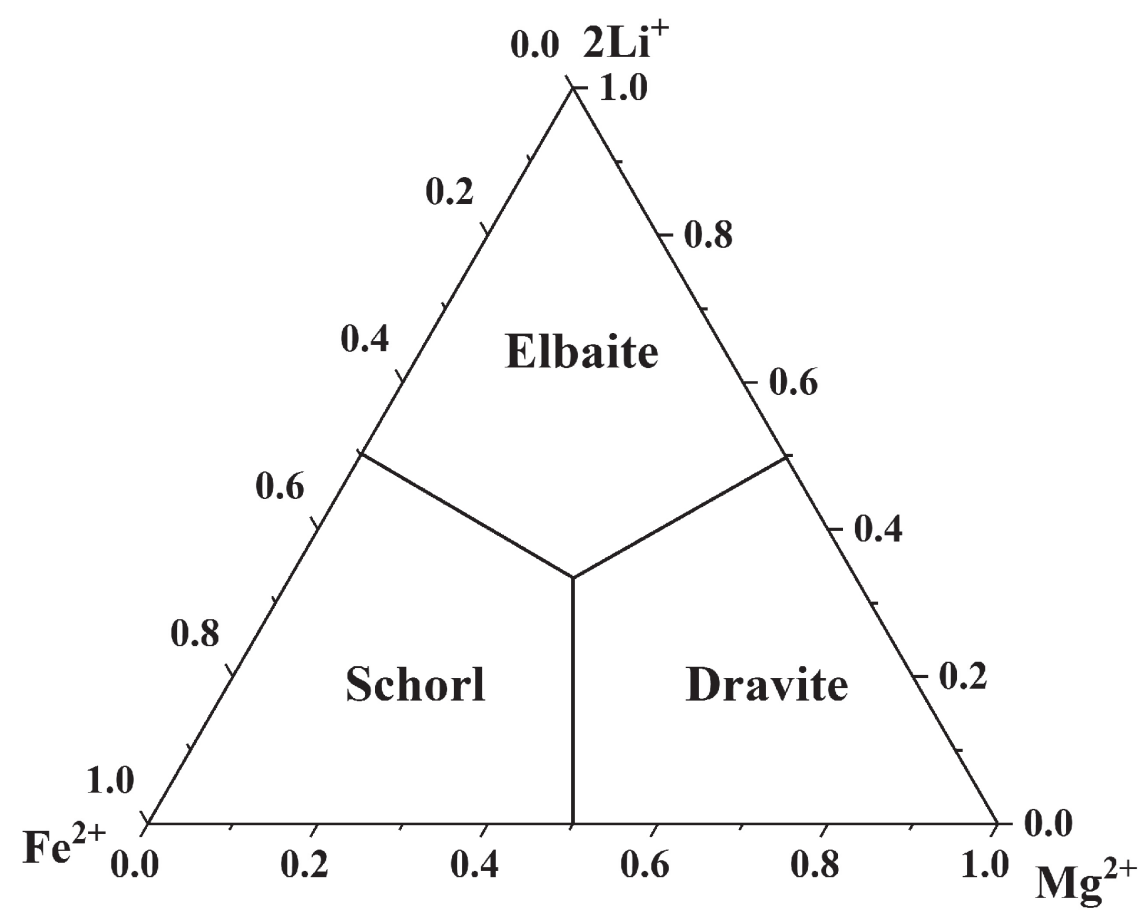

b

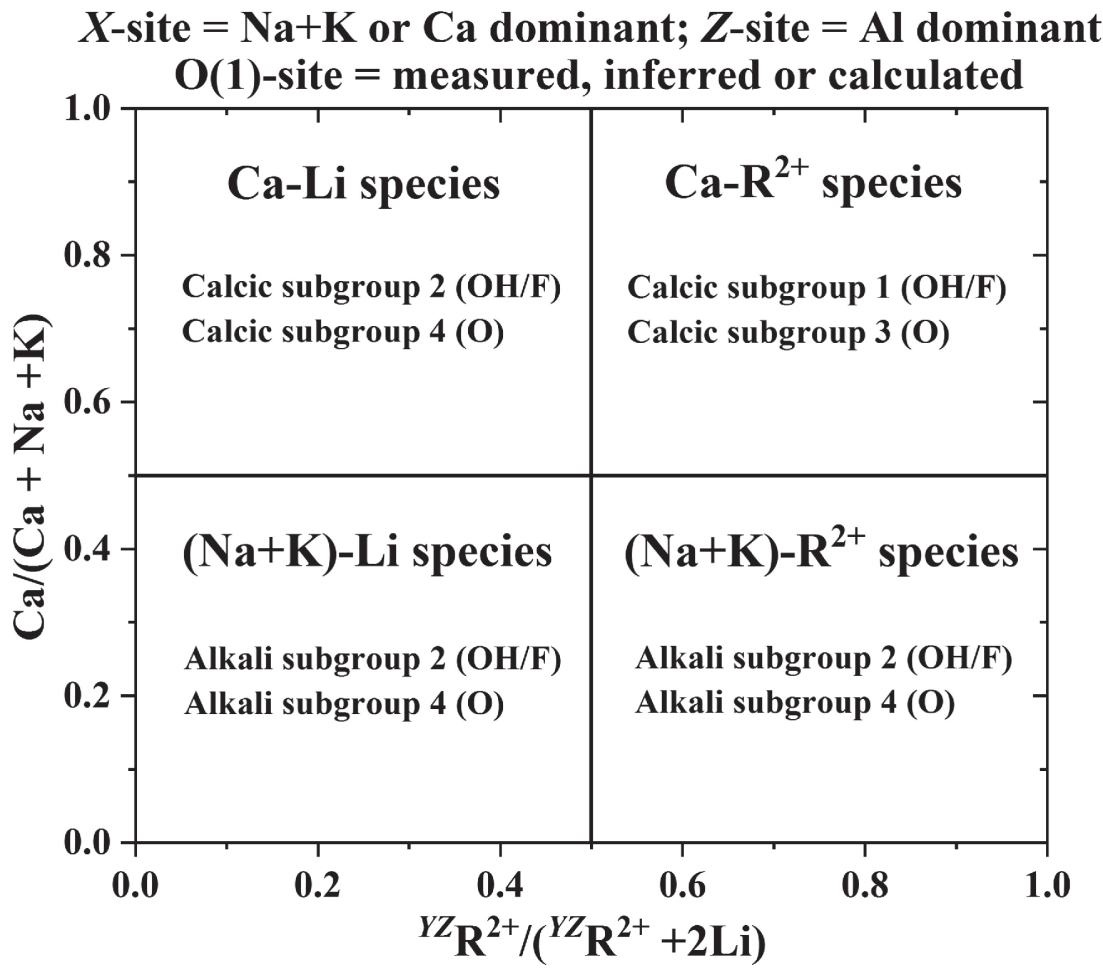

${ }^{40} \mathrm{Ar}-{ }^{39} \mathrm{Ar}$ ages of tourmaline are becoming a useful geochronological tool to decipher a range of tectonic events (e.g. Bea et al. 2009; Pesquera et al. 2009; Martinez-Martinez et al. 2010).

\subsection{Experimental mineralogy and petrology}

Earlier experimental investigations of tourmaline largely concentrated on synthesis of specific tourmaline compositions (e.g. von Goerne et al. 1999). Limited experimental investigations of the upper P-T stability range of tourmaline were done, but these experiments were rarely reversed (e.g. Frondel et al. 1947; Rosenberg et al. 1986; Henry and Dutrow 1990; Werding and Schreyer 1996; London 2011). After 1997, experimental studies were expanded to: (1) obtain data that allow estimation of aqueous fluid compositions based on tourmaline $X$-site composition (e.g. von Goerne et al. 2001, 2011; Berryman et al. 2015, 2016), (2) examine traceelement partitioning between tourmaline and melt (van Hins-

Fig. 7 Examples of tourmaline diagrams that can be used to visualize chemical variations and to guide classification. a - Tourmaline $\mathrm{Fe}^{2+}-\mathrm{Mg}-2 \mathrm{Li}$ subsystem for sodic-aluminous-hydroxy-tourmaline species. Note that this ternary is updated from the diagram that appeared in Henry et al. (2011). b - Diagram useful for establishing appropriate tourmaline subgroups within the aluminous alkali and calcic groups (modified after Henry et al. 2011). ${ }^{Y Z} \mathrm{R}^{2+}$ represents the total number of divalent cations at the $Y$ and $Z$ site. Determination of subgroups 1-4 uses a combination of the plotting parameters and the dominant anion of the dominant valency on the $\mathrm{O}(1)$ site. 
berg 2011), (3) establish boron isotopic fractionation involving tourmaline (e.g. Meyer et al. 2008; Marschall et al. 2009), and (4) to define possible boron release in subduction zones (e.g. Ota et al. 2008a).

Due to the lack of measured thermodynamic data on tourmaline, until recently most studies approximated thermodynamic parameters for tourmaline using a variety of methods (e.g. Dutrow et al. 1999; Garofalo et al. 2000; van Hinsberg and Schumacher 2007b). However, there are a small number of studies reporting measurements for the thermodynamic properties of a variety of tourmaline species (e.g. Ogorodova et al. 2012). Estimated tourmaline thermodynamic data have permitted calculation of fluid compositions in equilibrium with tourmaline (e.g. Dutrow et al. 1999;

Kister et al. 2005)

\section{Current trends and future possibilities}

Tourmaline studies have continued and will continue to progress and take advantage of new and improved instrumentation, but it is the unexpected developments that are the most exciting. A few speculations are presented in this section.

Petrologic and ore-deposit studies will likely refine methods in which the pressure- temperature-time relations of tour-

Fig. 8 Sodic oxy-tourmalines in the $\mathrm{Al}-\mathrm{Cr}-\mathrm{V}-\mathrm{Fe}^{3+}$ subsystem where oxytourmaline implies $>0.5 \mathrm{O}^{2-}$ apfu on the $O(1)$ site. The ternaries include trivalent cations at both the $Y$ and $Z$ sites to remove issues of uncertainty associated with order-disorder across these sites. End-member compositions are designated by the semi-circles along the triangle borders. Each species has a range of compositions that are labelled within the ternary systems. a - Sodic oxy-tourmalines in the $\mathrm{Al}-\mathrm{Cr}-\mathrm{V}$ subsystem at low $\mathrm{Fe}^{3+} \cdot \mathbf{b}$ - Sodic oxy-tourmalines in the $\mathrm{Al}-\mathrm{Cr}-\mathrm{Fe}^{3+}$ subsystem at low V. The species "vanadio-ferricpovondraite" is an inferred one and has yet to be described.

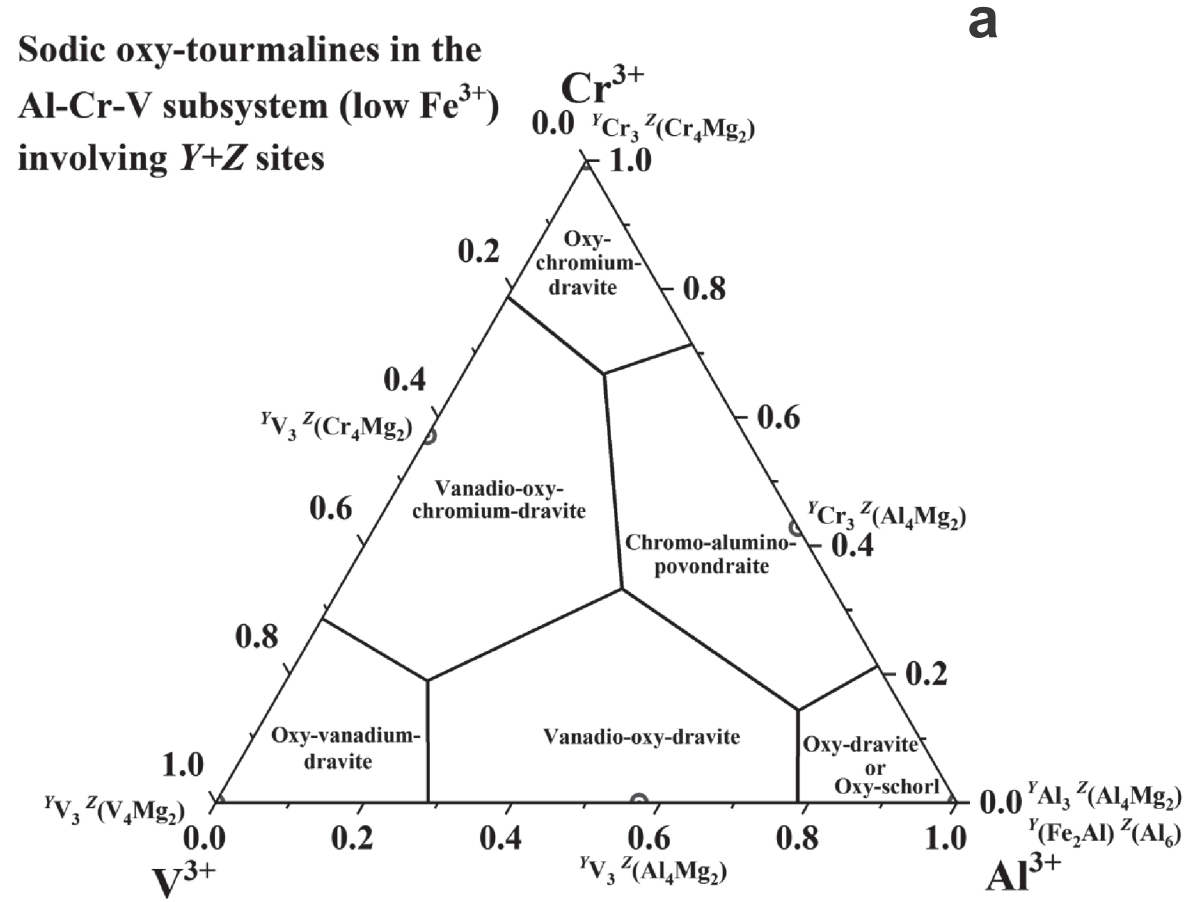

Sodic oxy-tourmalines in the
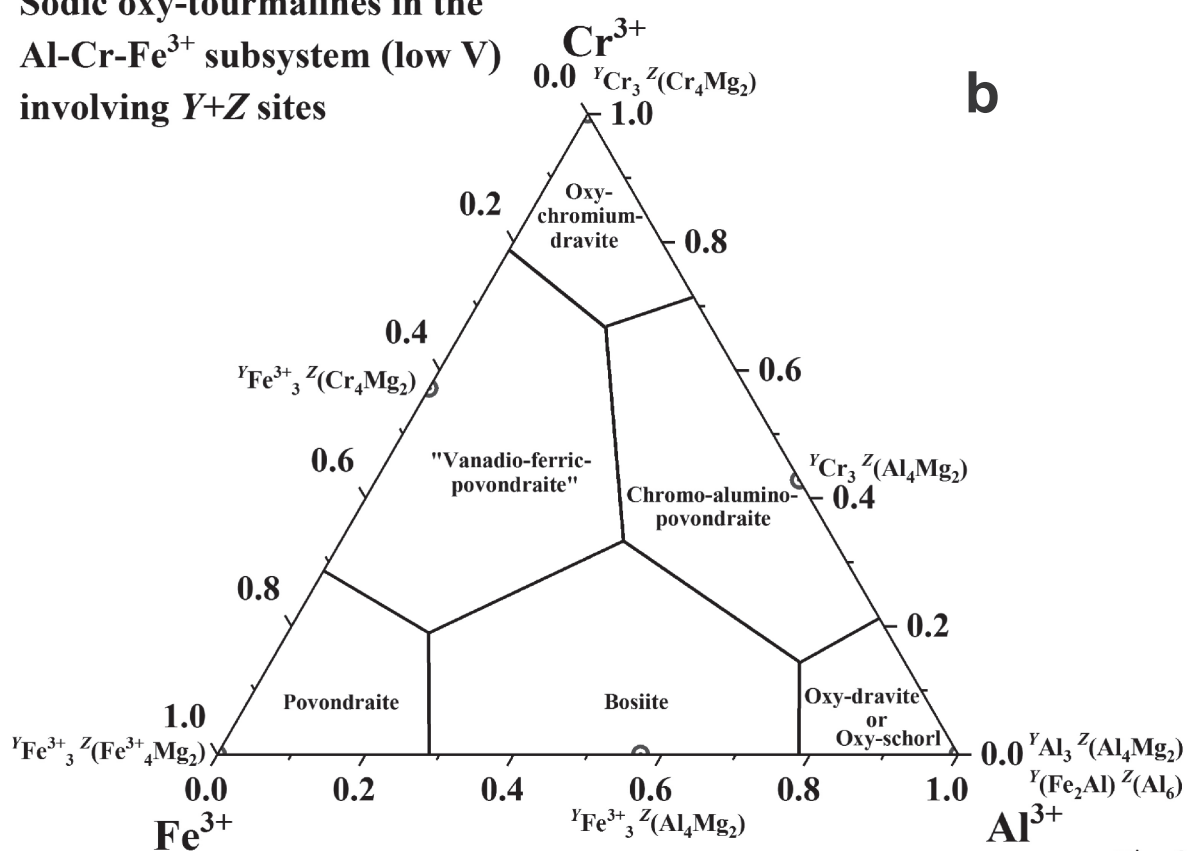
cal methods. Current and future studies in the isotopic realm will take advantage of the greatly improved spatial resolution to address fluid evolution associated with tourmaline growth (e.g. Duncan et al. 2006; Slack and Trumbull 2011), and P-T evolution using isotopic geothermobarometry (e.g. Dutrow et al. 2017). Research advances will likely target tourmaline characteristics as exploration tools for ore deposits.

Current and future directions of crystallographic studies will enhance understanding of the local environments in the tourmaline structure through complementary high-resolution X-ray diffraction and spectroscopic (e.g. FTIR, Raman, etc.) studies, and atom-probe studies to detect clustering, interface properties and potentially geochronology. Fourier-transform infrared, Raman and MAS-NMR spectroscopies of a "probe" ion such as $\mathrm{OH}^{-}$ or isotope such as ${ }^{27} \mathrm{Al}$ will provide insights into the local structural arrangements in tourmaline (e.g. Hawthorne 2016; Watenphul et al. 2016). There is currently broad agreement of band assignments in the vibrational spectra, but additional investigations will likely yield more specific assignments for the local arrangements in tourmaline (Hawthorne 2016). The amounts and locations of $\mathrm{Fe}^{2+}$ and $\mathrm{Fe}^{3+}$ in the tourmaline structures will be determined with greater accuracy from Mössbauer and synchrotron-based XANES studies (e.g. Cempírek et al. 2006; Andreozzi et al. 2008; Levy et al. 2017).

There will certainly be discoveries of several new tourmaline species. Potential new species could include $\mathrm{K}$-dominant tourmaline with a range of Y-site compositions, likely in UHP terrains, as well as K-dominant povondraite, $\mathrm{Pb}$-dominant dravite, and Ni-dominant tourmaline. Stabilization of these potential new species is dependent on $\mathrm{P}-\mathrm{T}$-fluid and on the partitioning of the relevant cations with the coexisting minerals.

As materials science becomes increasingly important to technological advancements, there are several applications that take advantage of the synergistic optical and electrical properties of tourmaline. These uses include applications such as acoustic wave sensors, photocatalysis, modification of glass properties and hazardous-waste remediation (e.g. Wang et al. 2014; Xu et al. 2014; Yu et al. 2016; Zhang et al. 2016; $\mathrm{Zu}$ et al. 2016). The future of these types of applications is promising, but large-scale deployment is uncertain.

Discovery of tourmaline on other planets may be just a matter of time. Based on relatively limited data on the bulk boron contents and $\mathrm{B} / \mathrm{Be}$ ratios of Mars and Venus, these planets are considered to be more enriched in boron than Earth (Shearer and Simon 2017). If these planets or their moons exhibit processes that fractionate boron in sufficient quantities, tourmaline may well be found in these extraterrestrial environments in the future.
Acknowledgments. We are indebted to Jan Cempírek and Milan Novák for organizing the Tourmaline 2017 International Symposium, for bringing together researchers from around the world, for facilitating these conference proceedings, and for providing a forum to ensure tourmaline studies will continue into the future. We thank our colleagues for thought-provoking discussions. Frank Hawthorne and Pavel Uher are thanked for their insightful reviews. Portions of this study benefited from National Science Foundation funding to DH and BD (grant number EAR-1551434).

\section{References}

Alty SW (1933) Some properties of authigenic tourmaline from Lower Devonian sediments. Amer Miner 18: $351-355$

Andreozzi GB, Bosi F, Longo M (2008) Linking Mössbauer and structural parameters in elbaite-schorl-dravite tourmalines. Amer Miner 93: 658-666

BAČíK P, CempíreK J, Uher P, Novák M, Ozdín D, Filip J, ŠKoda R, Breiter K, Klementová M, ĎuñA R, GroAT LA (2013) Oxy-schorl, $\mathrm{Na}\left(\mathrm{Fe}^{2+}{ }_{2} \mathrm{Al}\right)$ $\mathrm{Al}_{6} \mathrm{Si}_{6} \mathrm{O}_{18}\left(\mathrm{BO}_{3}\right)_{3}(\mathrm{OH})_{3} \mathrm{O}$, a new mineral from Zlatá Idka, Slovak Republic and Přibyslavice, Czech Republic. Amer Miner 98: 485-492

BAČÍK P, KodĚra P, UHER P, OzdÍN D, JÁNOŠíK M (2015) Chlorine-enriched tourmalines in hydrothermally altered diorite porphyry from the Biely Vrch porphyry gold deposit (Slovakia). Canad Mineral 53: 673-691

BADALOv ST (1951) Vanadium containing tourmaline and garnet. Zap Vsesojuz Mineral Obsh (Leningrad) 80: 212-213

Bea F, Pesquera A, Montero P, Torres-Ruiz J, GilCRESPO PP (2009) Tourmaline ${ }^{40} \mathrm{Ar} /{ }^{39} \mathrm{Ar}$ chronology of tourmaline-rich rocks from Central Iberia dates the main Variscan deformation phases. Geol Acta 7: 399-412

Belov NV, Belova BN (1949) Crystal structure of tourmaline. Dokl Akad Sci USSR 69: 185

Berryman EJ, Wunder B, Wirth R, Rhede D, Schettler G, Franz G, HeINRICH W (2015) An experimental study on K and $\mathrm{Na}$ incorporation in dravitic tourmaline and insight into the origin of diamondiferous tourmaline from the Kokchetav Massif, Kazakhstan. Contrib Mineral Petrol 169: 1-16

Berryman EJ, Wunder B, Ertl A, Koch-Müller M, Rhede D, Scheidl K, Giester G, Heinrich W (2016) P$\mathrm{T}-\mathrm{X}$ controls on $\mathrm{Ca}$ and $\mathrm{Na}$ distribution between $\mathrm{Mg}-\mathrm{Al}$ tourmaline and fluid. Contrib Mineral Petrol 171: 1-14

Berryman EJ, Kutzschbach M, Trumbull RB, MeiXner A, van Hinsberg V, Kasemann, SA, Franz G (2017) Tourmaline as a petrogenetic indicator in the Pfitsch Formation, Western Tauern Window, Eastern Alps. Lithos 284-285: 138-155 
BoAk JL, Dymek RF (1982) Metamorphism of the ca. 3800 Ma supracrustal rocks at Isua, West Greenland -implications for Early Archean crustal evolution. Earth Planet Sci Lett 59: 155-176

Bosi F, Reznitski L, Skogby H (2012) Oxy-chromiumdravite, $\mathrm{NaCr}_{3}\left(\mathrm{Cr}_{4} \mathrm{Mg}_{2}\right)\left(\mathrm{Si}_{6} \mathrm{O}_{18}\right)\left(\mathrm{BO}_{3}\right)_{3}(\mathrm{OH})_{3} \mathrm{O}$, a new mineral species of the tourmaline supergroup. Amer Miner 97: 2024-2030

Bosi F, Reznitski L, Skogby H, Halenius U (2014) Vanadio-oxy-chromium-dravite, $\mathrm{NaV}_{3}\left(\mathrm{Cr}_{4} \mathrm{Mg}_{2}\right)\left(\mathrm{Si}_{6} \mathrm{O}_{18}\right)$ $\left(\mathrm{BO}_{3}\right)_{3}(\mathrm{OH})_{3} \mathrm{O}$, a new mineral species of the tourmaline supergroup. Amer Miner 99: 1155-1162

Bosi F, Reznitski L, HÅlenius U, Skogby H (2017) Crystal chemistry of Al-V-Cr oxy-tourmalines from Sludyanka Complex, Lake Baikal, Russia. Eur J Mineral 29: 457-472

Brammall A (1921) Reconstitution processes in shales, slates, and phyllites. Mineral Mag 19: 211-224

Brammall A (1926) The Dartmoor granite. Proc Geol Assoc 37: 251-277

Branche G, Ropert ME (1956) Sur une association tourmaline-glaucophane. Compt Rend Acad Sci (Paris) 243: 387-389

BROWN LS (1929) Appearance of tourmaline in sediments. Amer Miner 14: 238-240

Brown LS (1931) Cap rock petrography. AAPG Bull 15: 509-529

BRUCE EL (1917) Magnesian tourmaline from Renfrew, Ontario. Mineral Mag 18: 133-135

Buerger MJ, PArrish W (1937) The unit cell and space group of tourmaline (an example of the inspective equiinclination treatment of trigonal crystals). Amer Miner 22: $1139-1150$

Buerger MJ, Burnham CW, Peacor DR (1962) Assessment of the several structures proposed for tourmaline. Acta Crystallogr 15: 583-590

BÜTTNER SH (2005) Deformation-controlled cation diffusion in compositionally zoned tourmaline. Mineral Mag 69: 471-489

BÜTTNER SH, KaSEMANN SA(2007) Deformation-controlled cation diffusion in tourmaline: a microanalytical study on trace elements and boron isotopes. Amer Miner 92: 1862-1874

Carobbi G, Pieruccini R (1947) Spectrographic analysis of tourmalines from the Island of Elba with correlation of color and composition. Amer Miner 32: 121-130

Cempírek J, Novák M, Ertl A, Hughes JM, Rossman GR, DYAR MD (2006) Fe-bearing olenite with tetrahedrally coordinated $\mathrm{Al}$ from an abyssal pegmatite at Kutná Hora, Czech Republic: structure, crystal chemistry, optical and XANES spectra. Canad Mineral 44: $23-30$

Collins JH (1883) Some Cornish tin-stones and tin-capels. Mineral Mag 5: 121-130
Dalrymple GB, LanPhere MA (1969) Potassium-Argon Dating. Principles, Techniques and Applications to Geochronology. W. H. Freeman, San Francisco, pp 1-258

DAmon PF, Kulp JL (1958) Excess helium and argon in beryl and other minerals. Amer Miner 43: 433-459

Deer WA, Howie RA, Zussman J (1962) Rock Forming Minerals. Longman, London, pp 300-319

DieTRICH RV (1985) The Tourmaline Group. Van Nostrand Reinhold Company, New York, pp 1-300

Donnay G (1969) Crystalline heterogeneity, evidence from electron-probe study of Brazilian tourmaline. Carnegie Inst Wash Yearb 67: 219-220

DONNAY G. BARTON R JR (1972) Refinement of the crystal structure of elbaite and the mechanism of tourmaline solid solution. Tschermarks mineral petrogr Mitt 18: 273-286

Donnay G, Buerger MJ (1950) The determination of the crystal structure of tourmaline. Acta Crystallogr 3: 379-388

Duchoslav M, Marks MaW, Drost K, McCammon C, Marschall HR, Wenzel T, Markl G (2017) Changes in tourmaline composition during magmatic and hydrothermal processes leading to tin-ore deposition: the Cornubian Batholith, SW England. Ore Geol Rev 83: 215-234

Duncan RJ, Wilde AR, Bassano K, MaAs R (2006) Geochronological constraints on tourmaline formation in the Western Fold Belt of the Mount Isa Inlier, Australia: evidence for large-scale metamorphism at $1.57 \mathrm{Ga}$ ? Precambr Res 146: 120-137

Duparc L, SigG, H (1914) Sur un gisement de tourmalines dans une serpentine de l'Oural. Bull Soc Franc Mineral 37: $14-19$

Dutrow BL, Henry DJ (2000) Complexly zoned fibrous tourmaline, Cruzeiro mine, Minas Gerais, Brazil: a record of evolving magmatic and hydrothermal fluids. Canad Mineral 38: 131-143

Dutrow B L, Henry DJ (2011) Tourmaline: a geologic DVD. Elements 7: 301-306

Dutrow BL, Henry DJ (2016) Fibrous tourmaline: a sensitive probe of fluid compositions and petrologic environments. Canad Mineral 54: 311-335

Dutrow BL, Holdaway MJ, Hinton RW (1986) Lithium in staurolite and its petrologic significance. Contrib Mineral Petrol 94: 496-506

Dutrow BL, Foster CT JR., Henry DJ (1999) Tourmalinerich pseudomorphs in sillimanite zone metapelites; demarcation of an infiltration front. Amer Miner 84: 794-805

Dutrow Bl, Marger K, Putlitz B, Henry DJ, Baumgartner L, Siron G, Bouvier A (2017) In-situ oxygen isotope study of tourmaline and quartz: insights into the prograde temperature history. Geol Soc Amer Abst Progr 49, Paper No. 106-13 
EDWARDS AB (1936) On the occurrence of quartz-tourmaline nodules in the granite of Clear Creek, near Everton. Proc Roy Victoria 49: 11-16

El-Hinnawi FF, Hofmann R (1966) Optische und chemische Untersuchungen an neun Turmalinen (Elbaiten). Neu Jb Mineral, Mh 1966: 80-89

Ertl A, Marschall HR, Giester G, Henry DJ, Schertl HP, Ntaflos T, Luvizotto GL, Nasdala L, Tillmanns E (2010) Metamorphic ultrahigh-pressure tourmaline: structure, chemistry, and correlations to $\mathrm{P}-\mathrm{T}$ conditions. Amer Miner 95: 1-10

FISHER J (2008) Gem pegmatites, southern California. In: Staebler GA, Wilson WW (eds) American Mineral Treasures. Lithographie LLC, East Hampton, Connecticut, pp 186-195

Fitch FJ, Miller JA (1972) ${ }^{40} \mathrm{Ar} /{ }^{39} \mathrm{Ar}$ dating of detrital tourmaline and tourmalinized rocks; schists and micas. J Geol Soc, London 128: 291-294

Frondel C (1948) Tourmaline pressure gauges. Amer Miner 33: 1-17

Frondel C, Collette RL (1957) Synthesis of tourmaline by reaction of mineral grains with $\mathrm{NaCl}-\mathrm{H}_{3} \mathrm{BO}_{3}$ solution, and its implications in rock metamorphism. Amer Miner 42: 754-758

Frondel C, Hurlbut CS, Collette RC (1947) Synthesis of tourmaline. Amer Miner 32: 680-681

Garofalo P, Audetat A, Gunther D, Heinrich CA, RIDLEY J (2000) Estimation and testing of standard molar thermodynamic properties of tourmaline endmembers using data of natural samples. Amer Miner 85: 78-88

Gatta GD, Bosi F, McIntyre GJ, Skogby H (2014) First accurate location of two proton sites in tourmaline: a single-crystal neutron diffraction study of oxy-dravite. Mineral Mag 78: 681-692

GAutier DL (1979) Preliminary report of authigenic, euhedral tourmaline crystals in a productive gas reservoir of the Tiger Ridge Field, north-central Montana. J Sediment Petrol 49: 911-916

Gautschi G (2002) Piezoelectric Sensorics: Force, Strain, Pressure, Acceleration and Acoustic Emission Sensors, Materials and Amplifiers. Springer-Verlag, Berlin, Heidelberg, New York, pp 1-264

Gordon SG (1944) The mineralogy of the tin mines of Cerro de Llallagua, Bolivia. Proc Acad Nat Sci Philadelphia 96: 279-359

Govorov IN (1971) Thermodynamic calculation and the interpretation of tourmaline systems. Tr Soveshch Eksp Tekh Mineral Petrogr 1968: 78-83

Grew ES (2017) Boron: from cosmic scarcity to 300 minerals. Elements 13: 225-229

Grew ES, BADA JL, HAZEN RM (2011) Borate minerals and origin of the RNA world. Origins Life Evol Biosphere 41: $307-316$
GrICE JD, ERCIT TS (1993) Ordering of Fe and Mg in the tourmaline crystal structure - the correct formula. Neu Jb Mineral, Abh 165: 245-266

Grice JD, ERcit TS, Hawthorne FC (1993) Povondraite, a redefinition of the tourmaline ferridravite. Amer Miner 78: $433-436$

GRIFFITH WP (1969) Raman studies on rock-forming minerals. Part I. Orthosilicates and cyclosilicates. J Chem Soc A (London): 1372-1377

GrunER W (1820) Die chemische Zusammensetzung des grönländischen Turmalins. Ann Phys Chem 65: 323-324

HALl A (1971) Greisenization in the granite of Cligga Head, Cornwall. Proc Geol Assoc 82: 209-230

HALL AL (1918) Note on a remarkable occurrence of chromium tourmaline and rutile in the Barberton district. Trans Geol Soc S Afr 20: 51-52

HAmburger GE, Buerger MJ (1948) The structure of tourmaline. Amer Miner 33: 532-540

Hamlin AC (1873) The Tourmaline. J. R. Osgood, Boston, pp $1-107$

HATERT F, Burke EAJ (2008) The IMA-CNMNC dominantconstituent rule revisited and extended. Canad Mineral 46: 717-728

HAWTHORne FC (1996) Structural mechanisms for lightelement variations in tourmaline. Canad Mineral 34: 123-132

HAWTHORNE FC (2016) Short-range atomic arrangements in minerals. I: the minerals of the amphibole, tourmaline and pyroxene supergroups. Eur J Mineral 28: 513-536

Hawthorne FC, Henry DJ (1999) Classification of the minerals of the tourmaline group. Eur J Mineral 11: 201-215

Hawthorne FC, Macdonald DJ, Burns PC (1993) Reassignment of cation site occupancies in tourmaline $\mathrm{Al}-\mathrm{Mg}$ disorder in the crystal-structure of dravite. Amer Miner 78: 265-270

Hazarika P, Upadhyay D, Pruseth KL (2017) Episodic tourmaline growth and re-equilibration in mica pegmatite from the Bihar Mica Belt, India: major-and trace-element variations under pegmatitic and hydrothermal conditions. Geol Mag 154: 68-86

HeALd MT (1955) Stylolites in sandstones. J Geol 63: $101-114$

Henry DJ, Dutrow BL (1990) Ca substitution in Li-poor aluminous tourmaline. Canad Mineral 28: 111-124

Henry DJ, Dutrow BL (1992) Tourmaline in a low grade clastic metasedimentary rock; an example of the petrogenetic potential of tourmaline. Contrib Mineral Petrol 112: 203-218

Henry DJ, Dutrow BL (1996) Metamorphic tourmaline and its petrologic applications. In: Grew ES, ANOVITZ LM (eds) Boron: Mineralogy, Petrology and Geochemistry. Mineralogical Society of America Reviews in Mineralogy 33: 503-557 
Henry DJ, Dutrow BL (2001) Compositional zoning and element partitioning in nickeloan tourmaline from a metamorphosed karstbauxite from Samos, Greece. Amer Miner 86: 1130-1142

Henry DJ, Dutrow BL (2012a) Tourmaline at diagenetic to low-grade metamorphic conditions: its petrologic applicability. Lithos 154, 16-32

Henry DJ, Dutrow BL (2012b) The tourmaline diaries: an eye-catching mineral and its many facets. Natur Hist 120: 16-27

Henry DJ, Guidotti CV (1985) Tourmaline as a petrogenetic indicator mineral - an example from the staurolitegrade metapelites of NW Maine. Amer Miner 70: 1-15

HENRY DJ, KiRKLAND BL, KIRKLAND DW (1999) Sectorzoned tourmaline from the cap rock of a salt dome. Eur J Mineral 11: 263-280

Henry DJ, Dutrow BL, Selverstone J (2004) Compositional asymmetry in replacement tourmaline - an example from the Tauern Window, Eastern Alps. Amer Miner 88: 1399

Henry DJ, Novák M, Hawthorne FC, Ertl A, Dutrow BL, Uher P, Pezzotta F (2011) Nomenclature of the tourmaline supergroup minerals. Amer Miner 96: 895-913

Hermon E, Sankin DJ, Donnay G, Muir WB (1973) The distribution of $\mathrm{Fe}^{2+}$ and $\mathrm{Fe}^{3+}$ in iron-bearing tourmalines: a Mössbauer study. Tschermarks Mineral Petrogr Mitt 19: $124-132$

HibBen JH (1939) The Raman Effect and Its Chemical Applications. Reinhold, New York, pp 1-428

Home RW (1976) Aepinus, the tourmaline crystal, and the theory of electricity and magnetism. Isis 67: 21-30

Hong W, CoOKe DR, Zhang L, Fox N, Thompson J (2017) Tourmaline-rich features in the Heemskirk and Pieman Heads granites from western Tasmania, Australia: characteristics, origins, and implications for tin mineralization. Amer Miner 102: 876-899

HuberT JF (1962) A zircon-tourmaline-rutile maturity index and the interdependence of the composition of heavy mineral assemblages with the gross composition and texture of sandstones. J Sediment Petrol 32: 440-450

Hutchison CS, LEOw JH (1963) Tourmaline greisenization at Langkawi, N.W. Malaya. Econ Geol 58: 587-592

HyršL J, Neumanová P (1999) Eine neue Gemmologische Untersuchung der Sankt Wenzelskrone in Prag. Zeit Deutsch Gemmol Gesell 48: 29-36

Iijima S, Cowley JM, Donnay G (1973) High resolution electron microscopy of tourmaline crystals. Tschermarks Mineral Petrogr Mitt 20: 216-224

IRVING EM (1937) Tourmalinization in the vicinity of the Cajalco tin mine, near Corona, California. Proc Geol Soc Amer 1936: 300-301

IYENGAR KYS (1937) Fibrous tourmalines from the Mysore State. Curr Sci 5: 534-535
JAHNS RH (1953) The genesis of pegmatites. I: occurrence and origin of large crystals. Amer Miner 38: 563-596

JAN MQ, SyMES RF, KEMPE DRC (1972) A chromian tourmaline from Swat, West Pakistan. Mineral Mag 38: 756-759

JEDWAB J (1962) Tourmaline zincifere dans une pegmatite de Muika (Congo). Soc Belge Geol Paleont Hydrol Bull 71: 132-135

Kalliomäki H, Wagner T, Fusswinkel T, SAKellaris G (2017) Major and trace element geochemistry of tourmalines from Archean orogenic gold deposits: proxies for the origin of gold mineralizing fluids? Ore Geol Rev 91: 906-927

Keys DA (1921) A piezoelectric method of measuring explosion pressures. Phil Mag 42: 473-488

KeYs DA (1923) On the adiabatic and isothermal piezoelectric constants of tourmaline. Phil Mag 46: 999-1001

Kister P, Vieillard P, Cuney M, Quirt D, Laverret E (2005) Thermodynamic constraints on the mineralogical and fluid composition evolution in a clastic sedimentary basin: the Athabasca Basin (Saskatchewan, Canada). Eur J Mineral 17: 325-341

KLAPRoth MH (1810) Chemische Untersuchung des gemeinen Schörls. Beit Chem Kennt Mineralkörp 5: 144-149

Kotzer TG, Kyser TK, King RW, Kerrich R (1993) An empirical oxygen isotope and hydrogen isotope geothermometer for quartz-tourmaline and tourmaline-water. Geochim Cosmochim Acta 57: 3421-3426

Kramer H, Allen RD (1954) Analyses and indices of refraction of tourmaline from Fault Gouge near Barstow, San Bernardino County, California. Amer Miner 39: 1020-1023

KRYNINE PD (1946) The tourmaline group in sediments. J Geol 54: 65-87

KulaszewsKi C (1921) Über die Kristallstruktur des Turmalins. In: RINNE F (eds) Röntgenographische Feinbaustudien. Abhandl Math phys kl sächs Akad Wiss Leipzig. Vieweg+Teubner Verlag, Wiesbaden; 81-117

Kunitz W (1929) Die Mischungsreihen in der Turmalingruppe und die genetischen Beziehungen zwischen Turmalinen und Glimmern. Chem Erde 4: 208-251

LaCroix A (1914) A propos de la tourmaline des serpentines. Bull Soc Franc Mineral 37: 75-76

LANG SB (2004) A 2400 year history of pyroelectricity: from Ancient Greece to exploration of the solar system. Brit Ceram Trans 103: 65-70

LAUSEN C (1926) Tourmaline-bearing cinnabar veins of the Mazatzal Mountains, Arizona. Econ Geol 21: 782-791

Levy E, Roy A, Henry D, Dutrow BL (2017) Geochemical analysis of tourmaline: coupling EPMA and XANES. In: Gadas P, NovÁK (eds) Tourmalines of the Eastern Part of the Bohemian Massif. Tigris, Zlín, pp 51-52

LONDON D (2011) Experimental synthesis and stability of tourmaline: a historical overview. Canad Mineral 49: 117-136 
LusSiER AJ, HAWTHORNe FC (2011) Oscillatory zoned liddicoatite from Anjanabonoina, Central Madagascar. II. Compositional variation and mechanisms of substitution. Canad Mineral 49: 89-104

Lussier A, Ball NA, Hawthorne FC, Henry DJ, Shimizu $\mathrm{R}$, Ogasawara Y, Ota T (2016) Maruyamaite, $\mathrm{K}\left(\mathrm{MgAl}_{2}\right)$ $\left(\mathrm{Al}_{5} \mathrm{Mg}\right) \mathrm{Si}_{6} \mathrm{O}_{18}\left(\mathrm{BO}_{3}\right)_{3}(\mathrm{OH})_{3} \mathrm{O}$, a potassium-dominant tourmaline from the ultrahigh-pressure Kokchetav Massif, northern Kazakhstan. Description and crystal structure. Amer Miner 101: 355-361

MacAlister DA (1903) Tin and tourmaline. Quart J Geol Soc London 59: 53-54

MANNING PG (1968) An optical absorption study of the origin of colour and pleochroism in pink and brown tourmalines. Canad Mineral 9: 678-690

Marfunin AS, Mkrtchyan AR, NaDZharyan GN, NynsSLK YM, Platonov AN (1970) Optical and Mössbauer spectra of iron in tourmalines. Izv Akad Nauk SSSR, Ser geol 2: 146-150

MARSCHALL HR, JiANG S-Y (2011) Tourmaline isotopes: no element left behind. Elements 7: 313-319

Marschall HR, Meyer C, Wunder B, Ludwig T, HeinRICH W (2009) Experimental boron isotope fractionation between tourmaline and fluid: confirmation from in situ analyses by secondary ion mass spectrometry and from Rayleigh fractionation modelling. Contrib Mineral Petrol 158: 675-681

Martinez-Martinez JM, Torres-Ruiz J, Pesquera A, GIL-Crespo PP (2010) Geological relationships and U$\mathrm{Pb}$ zircon and ${ }^{40} \mathrm{Ar} /{ }^{39} \mathrm{Ar}$ tourmaline geochronology of gneisses and tourmalinites from the Nevado-Filabride Complex (western Sierra Nevada, Spain): tectonic implications. Lithos 119: 238-250

Means AH (1914) Tourmaline-bearing gold quartz veins of the Michipicoten District, Ont. Econ Geol 9: 122-135

Meyer C, Wunder B, Meixner A, Romer RL, Heinrich W (2008) Boron-isotope fractionation between tourmaline and fluid: an experimental re-investigation. Contrib Mineral Petrol 156: 259-267

Mishima S, Ohtomo,Y, KaKegawa T (2016) Occurrence of tourmaline in metasedimentary rocks of the Isua Supracrustal Belt, Greenland: implications for ribose stabilization in Hadean marine sediments. Origins Life Evol Biosphere 46: 247-271

Moore JN, Christenson B, Aluis RG, Browne PRL, Lutz SJ (2004) The mineralogical consequences and behavior of descending acid-sulfate waters: an example from the Karaha-Telaga Bodas geothermal system, Indonesia. Canad Mineral 42: 1483-1499

NĚMEC D (1969) Fluorine in tourmalines. Contrib Mineral Petrol 20: 235-243

Novák M, ŠKoda R, Filip J, MaceK I, Vaculovič T (2011) Compositional trends in tourmaline from intragranitic NYF pegmatites of the Třebíč Pluton, Czech Republic: an electron microprobe, Mössbauer and LA-ICP-MS study. Canad Mineral 49: 359-380

Ogorodova LP, Melchakova LV, Kiseleva IA, PeretyAZHKO IS (2012) Thermodynamics of natural tourmalines - dravite and schorl. Thermochim Acta 539: 1-6

Ota T, Kobayashi K, Katsura T, Nakamura E (2008a) Tourmaline breakdown in a pelitic system: implications for boron cycling through subduction zones. Contrib Mineral Petrol 155: 19-32

Ota T, Kobayashi K, Kunihiro T, Nakamura E (2008b) Boron cycling by subducted lithosphere; insights from diamondiferous tourmaline from the Kokchetav ultrahigh-pressure metamorphic belt. Geochim Cosmochim Acta 72: 3531-3541

PALMER MR (1991) Boron isotope systematics of hydrothermal fluids and tourmalines - a synthesis. Chem Geol 94: $111-121$

PATTON HB (1899) Tourmaline and tourmaline schists from Belcher Hill, Colorado. Bull Geol Soc Amer 10: 21-26

PeCK LC (1964) Systematic Analysis of Silicates. US Geol Surv Bull 1170: pp 1-89

Penfield SL, Foote HW (1899) On the chemical composition of tourmaline. Amer J Sci 7: 97-125

Pesquera A, Torres-Ruiz J, Gil-Crespo PP, Roda-Robles E (2009) Multistage boron metasomatism in the Alamo Complex (Central Iberian Zone, Spain): evidence from field relations, petrography, and ${ }^{40} \mathrm{Ar} /{ }^{39} \mathrm{Ar}$ tourmaline dating. Amer Miner 94: 1468-1478

Pezzotta F, Laurs BM (2011) Tourmaline: the kaleidoscopic gemstone. Elements 7: 333-338

Plyusnina II, Granadchikova BG, Voskresenskaya IE (1969) An infra-red spectroscopic study of tourmalines. Sov Phys Crystallogr 14: 370-375

Popov VS, SADYKHOv TS (1962) Authigenic tourmaline from the Khodzha-Mumyn rock salt deposit. Dokl Akad Nauk SSSR 145: 1121-1122

POVONDRA P, ČECH F (1976) A method for the chemical analysis of tourmaline. Acta Univ Carol, Geol 1976: 209-218

Power GM (1968) Chemical variation in tourmalines from south-west England. Mineral Mag 37: 1078-1089

Reznitskit L, Clark CM, Hawthorne FC, Grice JD, SkogBy H, HÅlenius U, BosI F (2014) Chromo-aluminopovondraite, $\mathrm{NaCr}_{3}\left(\mathrm{Al}_{4} \mathrm{Mg}_{2}\right)\left(\mathrm{Si}_{6} \mathrm{O}_{18}\right)\left(\mathrm{BO}_{3}\right)_{3}(\mathrm{OH})_{3} \mathrm{O}$, a new mineral species of the tourmaline supergroup. Amer Miner 99: 1767-1773

RigGs RB (1888) The analysis and composition of tourmaline. Am J Sci 35: 35-51

ROBBINS CR, YODER HS JR (1962) Stability relations of dravite, a tourmaline. Carnegie Inst Wash Yearb 61: 106-108

ROBERT JL (1992) Cristallochimie du fluor dans tourmalines. Bull Soc franc Mineral Cristallogr 4: 43-44

Rosenberg PE, Foit FF, Ekambaram V (1986) Synthesis and characterization of tourmaline in the system $\mathrm{Na}_{2} \mathrm{O}$ $\mathrm{Al}_{2} \mathrm{O}_{3}-\mathrm{SiO}_{2}-\mathrm{B}_{2} \mathrm{O}_{3}-\mathrm{H}_{2} \mathrm{O}$. Amer Miner 71: 971-976 
Ruskin J (1894) The Ethics of the Dust: Ten Lectures to Little Housewives on the Elements of Crystallization. Henry Altemus, Philadelphia, pp 1-180

SCHARIZER R (1889) Ueber die chemische Constitution und über die Farbe der Turmaline von Schüttenhofen. Z Kristallogr 15: 337-365

Schreyer W, Abraham K, Behr HJ (1975) Sapphirine and associated minerals from the kornerupine rock of Waldheim, Saxony. Neu Jb Mineral, Abh 126: 1-27

Shearer CK, Simon SB (2017) Boron behavior during the evolution of the early solar System: the first 180 million years. Elements 13: 231-236

SCRIVENER JB (1910) The tourmaline-corundum rocks of Kiuta (Federated Malay States). Phil Mag 19: 655-656

Sillitoe RH, SAWKInS FJ (1971) Geologic, mineralogic, and fluid inclusion studies relating to the origin of copperbearing tourmaline breccia pipes, Chile. Econ Geol 66: 1028-1041

SLACK JF (1980) Tourmaline - A Prospecting Guide for Massive Base-Metal Sulfide Deposits in the Penobscot Bay Area, Maine. Special Economic Studies Series 8, Maine Geological Survey, Augusta, Maine, pp $1-25$

SLACK JF (1996) Tourmaline associations with hydrothermal ore deposits. In: GREw ES, ANOvitz LM (eds) Boron: Mineralogy, Petrology and Geochemistry. Mineralogical Society of America Reviews in Mineralogy 33: 559-664

Slack JF, Trumbull RB (2011) Tourmaline as a recorder of ore-forming processes. Elements 7: 321-326

SLAwson CB (1936) High-iron tourmaline from the Marquette Iron Range. Amer Miner 21: 195

SLIVko MM (1955) Tourmalinization in pegmatites. Mineral Sbor, L'vov Gosud Univ Frank 9: 181-215

SMITH DC (1971) A tourmaline-bearing eclogite from Sunnmoere, Norway. Norsk Geol Tidsskr 51: 141-147

SPENCER E (1925) Albite and other authigenic minerals in limestone from Bengal. Mineral Mag 20: 365-381

SPENCER LJ (1907) Notes on some Bolivian minerals (jamesonite, andorite, cassiterite, tourmaline). Mineral Mag 14: 308-344

SPERLICH R, Gieré R, Frey M (1996) Evolution of compositional polarity and zoning in tourmaline during prograde metamorphism of sedimentary rocks in the Swiss Central Alps. Amer Miner 81: 1222-1236

STOw MH (1932) Authigenic tourmaline in the Oriskany sandstone. Amer Miner 17: 150-157

Switzer GS (1974) Memorial of Martin L. Ehrmann, August 9, 1903 - May 18, 1972. Amer Miner 59: 414-415

TAYlor AM, Terell BC (1967) Synthetic tourmalines containing elements of the first transition series. J Cryst Growth 1: 238-244

TERMIER P (1907) Large tourmaline crystals from Ankaratra. Bull Soc Franc Mineral 31: 138-142
TILLEY CE (1919) The occurrence and origin of certain quartz-tourmaline nodules in the granite of Cape Willoughby. Trans Roy Soc S Austral 63: 156-165

TILLEY CE (1951) The zoned contact-skarns of the Broadford area, Skye: a study of boron-fluorine metasomatism in dolomites. Mineral Mag 29: 621-667

TomisaKa T (1968) Synthesis of some end-members of the tourmaline group. Mineral J 5: 355-364

Tressler JF, Alkoy S, Newnham RE (1998) Piezoelectric sensors and sensor materials. J Electroceram 2: 257-272

Trumbull RB, Slack JF, Krienitz MS, Belkin HE, WieDENBECK M (2011) Fluid sources and metallogenesis in the Blackbird $\mathrm{Co}-\mathrm{Cu}-\mathrm{Au}-\mathrm{Bi}-\mathrm{Y}-\mathrm{REE}$ District, Idaho, USA: insights from major-element and boron isotopic compositions of tourmaline. Canad Mineral 49: 225-244

TSANG T, GHOSE S (1973) Nuclear magnetic resonance of ${ }^{1} \mathrm{H},{ }^{7} \mathrm{Li},{ }^{11} \mathrm{~B},{ }^{23} \mathrm{Na}$ and ${ }^{27} \mathrm{~A} 1$ in tourmaline (elbaite). Amer Miner 58: 224-229

Tschermak G (1884) Lehrbuch der Mineralogie, IX. Hölder, Vienna, pp 1-589

Ushio M, SumiYoshi Y (1971) Synthesis of large industrial single crystals: 1 . Hydrothermal synthesis of dravitetourmaline. Kogyo Kagaku Zasshi 74: 2252-2259

VAn Hinsberg VJ (2011) Preliminary experimental data on trace-element partitioning between tourmaline and silicate melt. Canad Mineral 49: 153-163

VAN Hinsberg VJ, Schumacher JC (2007a) Intersector element partitioning in tourmaline: a potentially powerful single crystal thermometer. Contrib Mineral Petr 153: 289-301

van Hinsberg VJ, Schumacher JC (2007b) Using estimated thermodynamic properties to model accessory phases: the case of tourmaline. J Metamorph Geol 25: 769-779

van Hinsberg VJ Schumacher JC (2011) Tourmaline as a petrogenetic indicator mineral in the Haut-Allier Metamorphic Suite, Massif Central, France. Canad Mineral 49: 177-194

van Hinsberg VJ, Schumacher JC, Kearns S, Mason PRD, Franz G (2006) Hourglass sector zoning in metamorphic tourmaline and resultant major and traceelement fractionation. Amer Miner 91: 717-728

van Hinsberg VJ, Henry DJ, Marschall HR (2011a) Tourmaline: an ideal indicator of its host environment. Canad Mineral 49: 1-16

van Hinsberg VJ, Henry DJ, Dutrow BL (2011b) Tourmaline as a petrologic forensic mineral: a unique recorder of its geologic past. Elements 7: 327-332

van Hinsberg VJ, Franz G, Wood BJ (2017) Determining subduction-zone fluid composition using a tourmaline mineral probe. Geochem Perspect Lett 3: 160-169

Vierne R, BRUnel R (1970) Spectre de reflexion infrarouge de la tourmaline. Compt Rend Acad Sci (Paris) 270: $488-490$ 
VOn Goerne G, Franz G, Robert JL (1999) Upper thermal stability of tourmaline plus quartz in the system $\mathrm{MgO}$ $\mathrm{Al}_{2} \mathrm{O}_{3}-\mathrm{SiO}_{2}-\mathrm{B}_{2} \mathrm{O}_{3}-\mathrm{H}_{2} \mathrm{O}$ and $\mathrm{Na}_{2} \mathrm{O}-\mathrm{MgO}-\mathrm{Al}_{2} \mathrm{O}_{3}-\mathrm{SiO}_{2}-$ $\mathrm{B}_{2} \mathrm{O}_{3}-\mathrm{H}_{2} \mathrm{O}-\mathrm{HCl}$ in hydrothermal solutions and siliceous melts. Canad Mineral 37: 1025-1039

von Goerne G, Franz G, Heinrich W (2001) Synthesis of tourmaline solid solutions in the system $\mathrm{Na}_{2} \mathrm{O}-\mathrm{MgO}-$ $\mathrm{Al}_{2} \mathrm{O}_{3}-\mathrm{SiO}_{2}-\mathrm{B}_{2} \mathrm{O}_{3}-\mathrm{H}_{2} \mathrm{O}-\mathrm{HCl}$ and the distribution of $\mathrm{Na}$ between tourmaline and fluid at 300 to 700 degrees $\mathrm{C}$ and $200 \mathrm{MPa}$. Contrib Mineral Petrol 141: 160-173

von Goerne G, Franz G, van Hinsberg VJ (2011) Experimental determination of $\mathrm{Na}-\mathrm{Ca}$ distribution between tourmaline and fluid in the system $\mathrm{CaO}-\mathrm{Na}_{2} \mathrm{O}-\mathrm{MgO}-$ $\mathrm{Al}_{2} \mathrm{O}_{3}-\mathrm{SiO}_{2}-\mathrm{B}_{2} \mathrm{O}_{3}-\mathrm{H}_{2} \mathrm{O}$. Canad Mineral 49: 137-152

WALENTA K, DunN PJ (1979) Ferridravite, a new mineral of the tourmaline group from Bolivia. Amer Miner 64: 945-948

WALTON SA (2001) Theophrastus on Lyngurium: medieval and early modern lore form the classical lapidary tradition. Ann Sci 58: 357-379

Wang CP, Yu L, Zhang ZY, Wang BL, Sun HW (2014) Tourmaline combined with Phanerochaete chrysosporium to remediate agricultural soil contaminated with PAHs and OCPs. J Hazard Mater 264: 439-448

Watenphul A, Burgdorf M, Schlüter J, Horn I, MalCHEREK T, MiHailova B (2016) Exploring the potential of Raman spectroscopy for crystallochemical analyses of complex hydrous silicates: II. Tourmalines. Amer Miner 101: 970-985

WATSON TL (1902) On the occurrence of aplite, pegmatite and tourmaline bunches in the Stone Mountain granite of Georgia. J Geol 10: 186-193
WeIs PL (1953) Fluid inclusions in minerals from zoned pegmatites of the Black Hills, South Dakota. Amer Miner 38: 671-697

Werding G, Schreyer W (1996) Experimental studies on borosilicates and selected borates. In: GREW ES, Anovitz LM (eds) Boron: Mineralogy, Petrology and Geochemistry. Mineralogical Society of America Reviews in Mineralogy 33: 117-163

Wethered E (1888) On insoluble residues. Quarter J Geol Soc London 44: 186-199

WIEGLEB JC (1785) Chemische Untersuchung des schwarzen Stangenschörls. Chem Ann Freunde Natur, Arzn, Haush Manufact (Crells Chemische Annalen) 1 Stück: 246-253

Xu H, Liu WC, Shi J, Zhao H, Qi SY (2014) Photocatalytic discoloration of Methyl Orange by anatase/schorl composite: optimization using response surface method. Environ Sci Pollut Res 21: 1582-1591

Yu L, Wang CP, Chen FY, Zhang JQ, Ruan YF, Xu JY (2016) Investigating the synergistic effects in tourmaline/ $\mathrm{TiO}_{2}$-based heterogeneous photocatalysis: underlying mechanism insights. J Mol Catal A: Chem 411: 1-8

Zhang H, Meng J, Liang J, LiU J, Zeng Z (2016) Effect of the dosage of tourmaline on far infrared emission properties of tourmaline/glass composite materials. J Nanosci Nanotechnol 16: 3899-3903

ZHeLUdeV IS, BeLOV VF (1967) Mössbauer effect in tourmaline and $\mathrm{BaTi}_{0.75} \mathrm{Sn}_{0.25} \mathrm{O}_{3}$ solid solution. Izv Akad Nauk SSSR Fiz Zemli 31: 1117-1119

Zu H, Wu H, WANG Q-M (2016) High-temperature piezoelectric crystals for acoustic wave sensor applications. IEEE Trans Ultrason Ferroelectr Freq Control 63: 486-505 